\title{
Diagenetic Fluid and Its Impact on Sandstone Reservoirs in the Southern Boxing Sag, Dongying Depression, Bohai Bay Basin, China
}

\author{
Zhenhuan Shen $\mathbb{D},{ }^{1}$ Zhuang Ruan $\mathbb{D}^{1},{ }^{1}$ Bingsong Yu $\mathbb{D},{ }^{1}$ Shujun Han, ${ }^{1}$ Chenyang Bai, ${ }^{2}$ \\ Qiuhong Chang, ${ }^{1}$ and Tianxia $\mathrm{An}^{3}$ \\ ${ }^{1}$ School of Geosciences and Resources, China University of Geosciences, Beijing 100083, China \\ ${ }^{2}$ School of Ocean Sciences, China University of Geosciences, Beijing 100083, China \\ ${ }^{3}$ Research Institute of Exploration and Development, Shengli Oilfield Company, Sinopec, Dongying 257015, China \\ Correspondence should be addressed to Zhuang Ruan; ruanz0103@cugb.edu.cn
}

Received 19 October 2021; Revised 7 December 2021; Accepted 8 December 2021; Published 10 January 2022

Academic Editor: Chris Harris

Copyright (c) 2022 Zhenhuan Shen et al. This is an open access article distributed under the Creative Commons Attribution License, which permits unrestricted use, distribution, and reproduction in any medium, provided the original work is properly cited.

\begin{abstract}
Diagenesis typically exerts a crucial impact on the formation of high-quality sandstone reservoirs in the Eocene Shahejie Formation, Dongying Depression. To better understand the formation process of petrophysical properties, this research conducts petrographic and geochemical analyses to investigate the nature of diagenetic fluids. Petrographic observations suggest that the dominant cements are carbonate, authigenic quartz, and clay minerals, accompanied with the dissolution of feldspar and calcite. The homogenization temperature of aqueous inclusions in quartz overgrowth usually exceeds $90^{\circ} \mathrm{C}$ corresponding to the maturity of organic matter. Quartz overgrowths contain higher amounts of $\mathrm{CaO}$ and $\mathrm{Al}_{2} \mathrm{O}_{3}$ than detrital quartz. This indicates that the siliceous fluid mainly originates from the dissolution of feldspar. Moreover, the conversion of clay minerals also provides trace amounts of silica into pore water during the burial process. Carbonate cements consist of early-stage calcite as well as late-stage Fe-calcite and ankerite. Calcite with relatively higher MnO proportions shows yellow luminescence and dissolution signs. Fe-calcite and ankerite cements have a higher homogenization temperature than that of quartz overgrowth and mainly concentrate in $\mathrm{FeO}$ and $\mathrm{MgO}$ as well as contain a small amount of $\mathrm{Na}^{+}, \mathrm{K}^{+}$, and $\mathrm{Sr}^{2+}$. The rare earth element (REE) pattern of bulk mudstone and carbonate cements as well as $\mathrm{C}-\mathrm{O}$ isotopic evidences indicate that the diagenetic fluids of carbonate cementation are primarily controlled by the adjacent mudstone, whereas mineral dissolution and altered clay minerals in sandstone provide additional cations for the local reprecipitation of late-stage carbonate. Therefore, diagenetic fluids within sandstone reservoirs are typically subject to alkaline-acid-alkaline conditions and are influenced by internal sources in a closed system. Compaction significantly reduces the pore space of sandstone reservoirs in the Boxing Sag. Carbonate cementation further increases the complexity of pore structure and obeys the principle of mass balance.
\end{abstract}

\section{Introduction}

Diagenesis including compaction, cementation, metasomatism, and dissolution crucially determines the development of pore space within siliciclastic rock reservoirs (e.g., [1-4]). In particular, cementation and dissolution are closely related to the geochemical properties of pore fluids and record the signal of water-rock reactions during progressive diagenesis $[5,6]$. Nevertheless, the characteristics of pore fluids are typically complicated and vary in different diagenetic stages $[7,8]$. Thus, it is significant to comprehend the diagenetic stages and fluid properties in burial environment for revealing the evolution of diagenetic fluids and the formation of high-quality reservoirs [9]. Currently, several reliable methods for dividing diagenetic stages exist, including clay mineral composition, vitrinite reflectance, and organic matter maturity $[3,10,11]$. However, the origin of fluids, temperature conditions for fluid activity, and transformation 

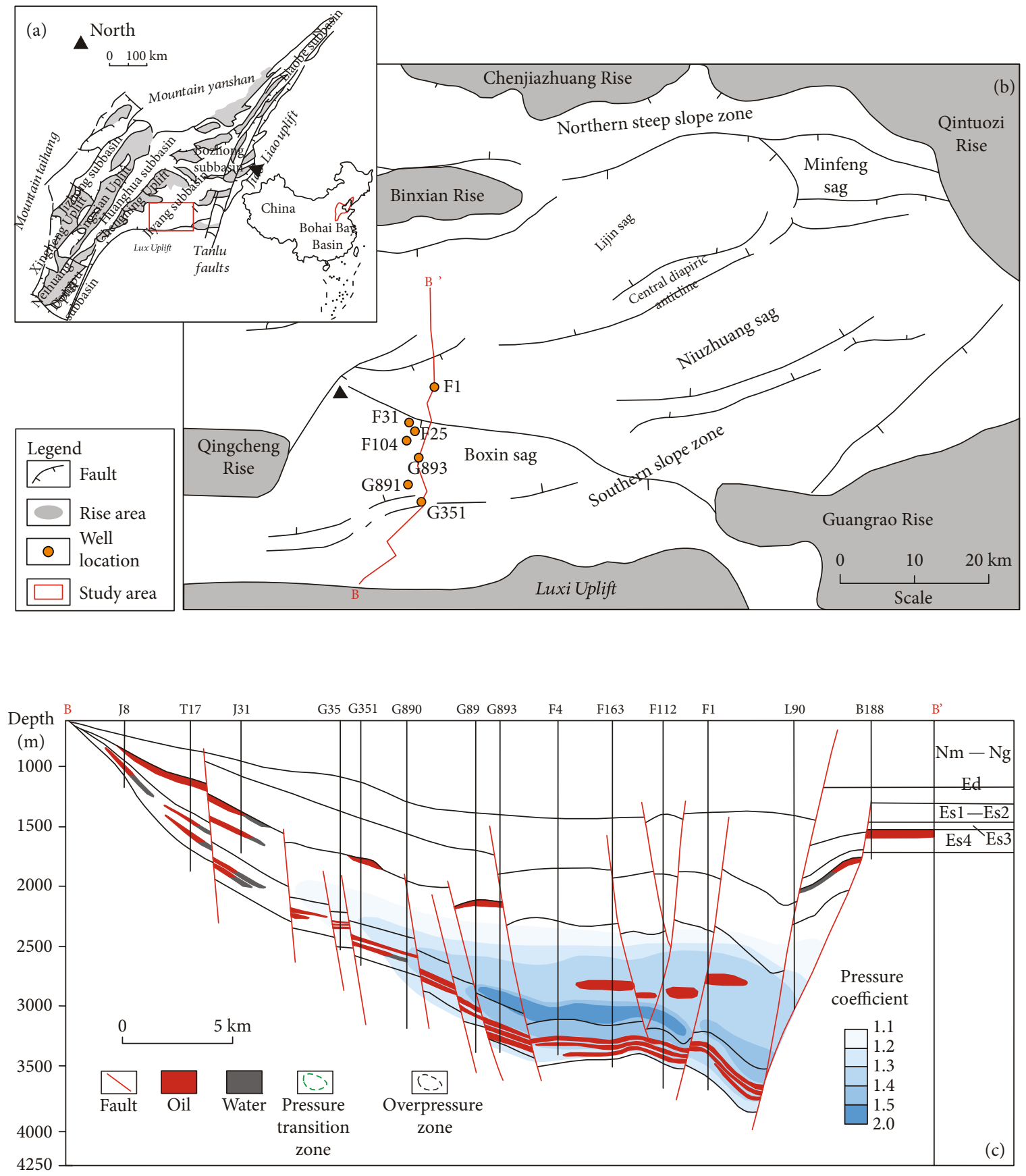

Figure 1: (a, b) Structural map of the Bohai Bay Basin and tectonic setting of the Dongying Depression. (c) Cross-section of B-B' in the Boxing Sag (modified from [64]).

time of diagenetic fluids are still debatable $[12,13]$. The use of major and minor elements together with $\mathrm{C}-\mathrm{O}$ isotope of carbonate minerals was the most widespread methods to track the source of fluids and the organic-inorganic reactions in siliciclastic rock reservoirs (e.g., [14-19]). Fluid inclusions within authigenic minerals were conducted to ascertain the time of fluid combining with the burial history [20-22] and provided additional evidence to distinguish the origin of diagenetic fluids [23]. Over the past few years, electron probe microanalysis (EPMA), laser ablation inductively coupled plasma-mass spectrometry (LA-ICP-MS), and sec- ondary ion mass spectrometry (SIMS) were gradually applied in diagenetic fluid research owing to the development of in situ testing technologies (e.g., [24-26]), which helped in revealing fluid characteristics and in understanding diagenetic transformation during the burial process.

The Eocene Shahejie Formation in the Boxing Sag, southern Dongying Depression, is a significant oil-bearing reservoir, which primarily comprises interbedded very finegrained sandstones, siltstones, and mudstones in an open littoral and shallow lacustrine sedimentary environment [27-29]. Sandstones in the Shahejie Formation normally 

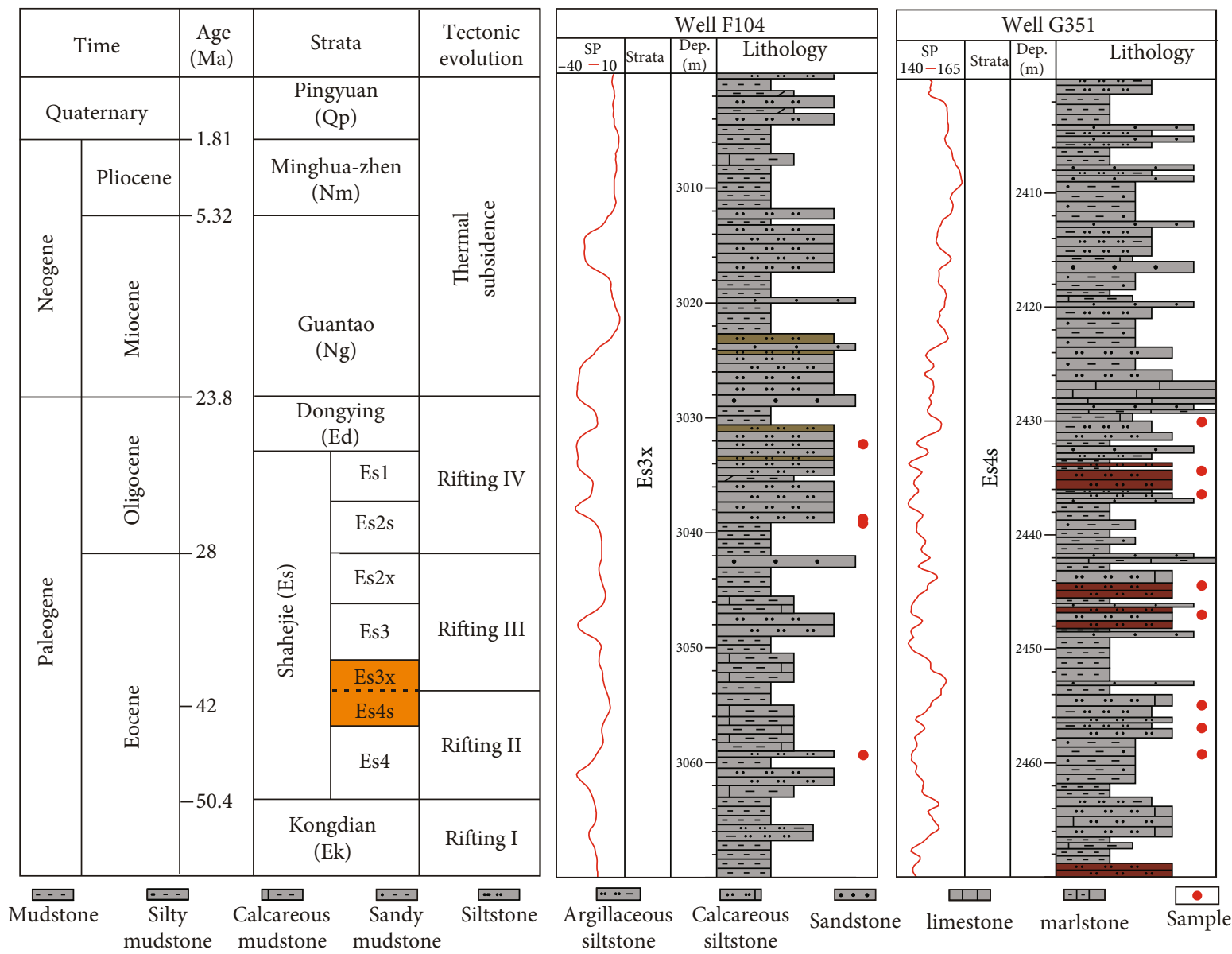

Figure 2: Tertiary stratigraphy and tectonic evolution of the Dongying Depression; sedimentary sequence of wells F104 and G351 in the Es3x and Es4s, respectively, and their locations are shown in Figure 1(b).

TABLE 1: Thin-section compositions from optical point counting and quantitative image analysis.

\begin{tabular}{|c|c|c|c|c|c|c|c|c|c|c|c|c|}
\hline \multirow[b]{2}{*}{ Well } & \multicolumn{8}{|c|}{ Grain size $(\mathrm{mm}), \%$} & \multirow[b]{2}{*}{$\begin{array}{c}\text { Quartz, } \\
\%\end{array}$} & \multirow[b]{2}{*}{$\begin{array}{c}\text { K-feldspar, } \\
\%\end{array}$} & \multirow[b]{2}{*}{$\begin{array}{c}\text { Plagioclase, } \\
\%\end{array}$} & \multirow[b]{2}{*}{$\begin{array}{c}\text { Rock fragment, } \\
\%\end{array}$} \\
\hline & Strata & No. & $\begin{array}{c}0.031- \\
0.063\end{array}$ & $\begin{array}{c}0.063- \\
0.125\end{array}$ & $\begin{array}{c}0.125- \\
0.25\end{array}$ & $\begin{array}{c}0.25- \\
0.50\end{array}$ & $S_{\mathrm{o}}$ & No. & & & & \\
\hline $\mathrm{F} 1$ & Es4 & 3 & 14.2 & 60.9 & 24.9 & 0 & 1.6 & 6 & 40.7 & 14.4 & 18.2 & 26.7 \\
\hline F25 & Es3 & 2 & 0 & 10.1 & 52.2 & 37.7 & 1.5 & 2 & 43.5 & 16.0 & 20.0 & 20.5 \\
\hline F104 & Es3 & 2 & 0.5 & 35.85 & 58.7 & 4.95 & 1.6 & 17 & 39.4 & 15.7 & 19.3 & 25.7 \\
\hline G351 & Es4 & 2 & 6.7 & 60.95 & 31.15 & 1.2 & 1.5 & 16 & 48.3 & 16.5 & 17.5 & 17.7 \\
\hline G891 & Es4 & 1 & 12.1 & 63.3 & 24.3 & 0.3 & 1.6 & 2 & 46.4 & 17.9 & 19.8 & 15.9 \\
\hline \multirow[t]{2}{*}{ G893 } & Es4 & 2 & 18.8 & 68.3 & 12.9 & 0 & 1.5 & 7 & 45.9 & 17.7 & 19.6 & 15.8 \\
\hline & & & 7.5 & 49.9 & 34.0 & 7.4 & & AVG. & 44.1 & 16.4 & 19.1 & 20.4 \\
\hline
\end{tabular}

Sorting coefficient $S_{0}=P_{25} / P_{75}, P_{25}$, and $P_{75}$ are the grain sizes at $25 \%$ and $75 \%$, respectively.

underwent complicated diagenesis. Previous studies have demonstrated that compaction is the primary factor for reducing the reservoir properties, followed by cementation, further increasing the heterogeneities of the pore structure as well as decreasing the reservoir porosity and permeability $[21,22,30]$. Carbonate minerals, authigenic quartz, and clay minerals are the most common diagenetic cements within sandstones in the Boxing Sag. The distance from sandstone to mudstone has a crucial influence on carbonate precipitation because compacted mudstones release sufficient ions into pore water [30,31]. The silica source for quartz overgrowth normally stems from feldspar dissolution and is mainly determined by the petrographic evidences $[6,29]$. However, few comprehensive studies have focused on the characteristics and sources of fluids for carbonate and quartz cements to explain diagenetic transformation within 


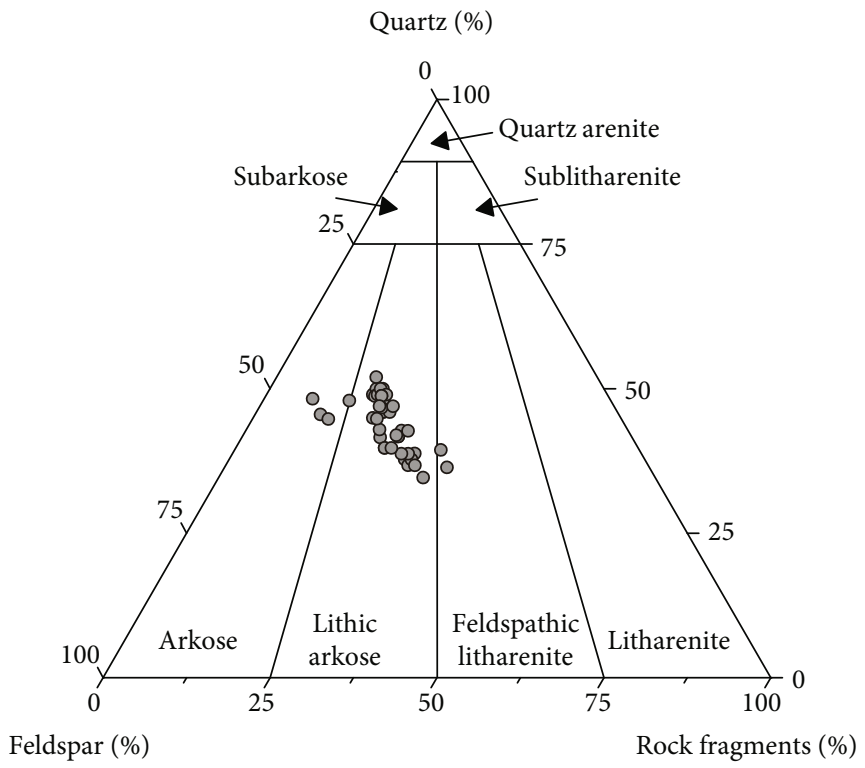

Figure 3: Rock composition of the beach-bar sandstones in the Boxing Sag. Based on the classification standard of Folk et al. [35].

reservoirs in the Boxing Sag. Additionally, mineral dissolution induced by the thermal evolution of organic matter in an open or closed diagenetic system probably determines whether the by-products mass transfer and reservoir quality can be improved $[32,33]$. Therefore, the research of diagenetic fluid provides valuable information about the cementation origin and helps in further exploring the water-rock reactions and fluid migration within reservoirs.

This study is primarily aimed at revealing the characteristics and origins of diagenetic fluids and their influence on sandstone reservoirs. We focused on (1) building the diagenetic sequences of sandstone reservoirs using petrographic features, (2) utilizing quantitative methods, including the homogenization temperature of fluid inclusions, major and trace elements, and stable isotopic analysis to investigate the sources and transformation time of diagenetic fluids, and (3) discussing the geochemical diagenesis system and its impact on the quality of reservoirs in the Eocene Shahejie Formation beach-bar sandstones.

\section{Geological Setting}

The Bohai Bay Basin, located in eastern China, is an important hydrocarbon-producing basin. It comprises several subbasins and covers approximately $200,000 \mathrm{~km}^{2}$ (Figure 1(a)). The Jiyang Subbasin is bounded by the Tanlu Fault to the east, Chengning Uplift to the northwest, and Luxi Uplift to the south. The Dongying Depression is a secondary tectonic unit of the Jiyang Subbasin and has an area of approximately $5700 \mathrm{~km}^{2}$ (Figure $1(\mathrm{~b})$ ). It is situated in the southeastern part of the Jiyang Subbasin and is bordered by the Luxi Uplift to the south, Guangrao rise to the southeast, Chengjiazhuang rise to the north, and Binxian and Qingcheng rises to the west. The Dongying Depression comprises the southwestern Boxing, central Niuzhuang, northwestern Lijing, northeastern Minfeng sags, and central diapiric anticline (Figure 1(c)).
The Boxing Sag, the study area, contains Cenozoic sediments hosting six formations, upward namely the Paleogene Kongdian (Ek), Shahejie (Es) and Dongying (Ed), Neogene Guantao $(\mathrm{Ng})$ and Minghuazhen $(\mathrm{Nm})$, and Quaternary Pingyuan (Qp) formations. The Es Formation is divided into four members: Es1, Es2, Es3, and Es4, from the top to the bottom in the specified order. The Es4 and Es3 members can be further divided into several submembers based on the differences in petrological properties. These submembers are called Es4x, Es4s, Es3x, Es3z, and Es3s from the bottom to the top. The Es4s and Es3x, which are dominated by thinbedded very fine-grained sandstones and siltstones interbedded with mudstone, are the research objects of this study (Figure 2). During the Es4s sedimentary period, the different sags in the Dongying Depression were connected. Furthermore, the sand bodies of a deltaic deposit were developed on the southern gentle slope with an abundant supply of fluvial sediments. Owing to the development of certain humps on the gentle slope and the subsequent wave action, characteristic beach-bar sandstones deposited in the broad-shore shallow-lake environment and frequently interbedded with mudstone and shale [27]. This depression entered a relatively deep-lacustrine environment during the Es3 sedimentary period because the basement quickly subsided [34]. Sand bodies of deltaic deposits can be found at the south and west margins of the Boxing Sag. Meanwhile, it is characterized by beach-bar sandstones mixed with micrite and oolitic limestones in thick mudstones in the central part of the study area.

\section{Materials and Methods}

A total of 30 samples from 7 wells (F25, G351, and F104 in the Es3x interval; F1, G893, G891, and G351 in the Es4s interval) in the Boxing Sag were prepared into blue epoxy resin-immersed thin sections $(30 \mu \mathrm{m}$ thickness $)$ 


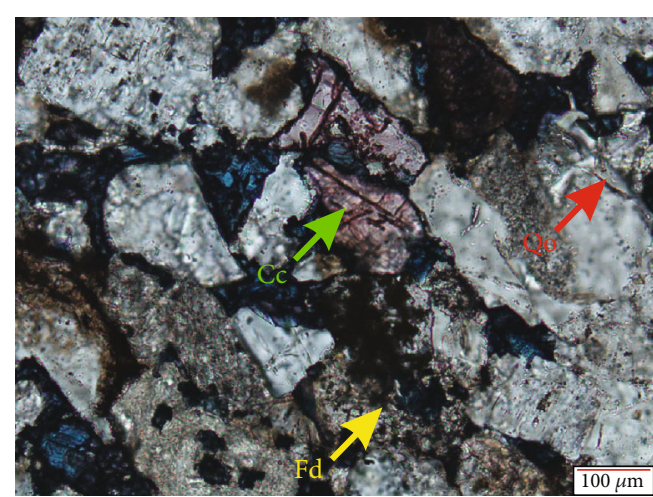

(a)

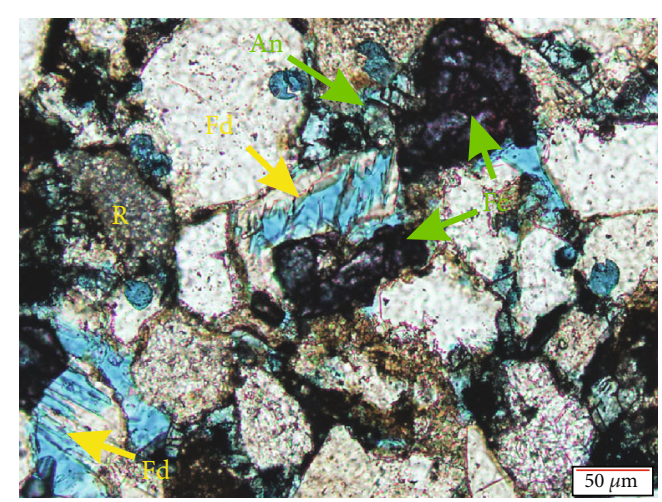

(c)

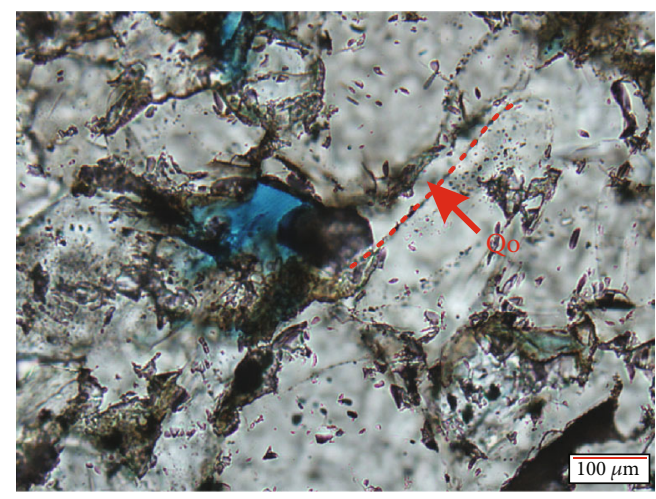

(e)

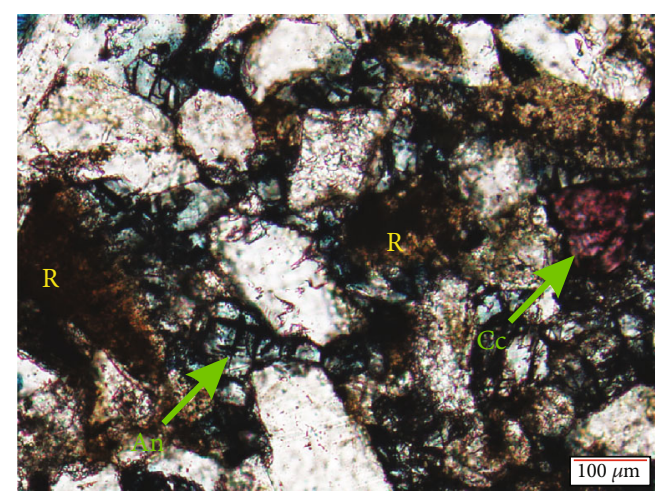

(g)

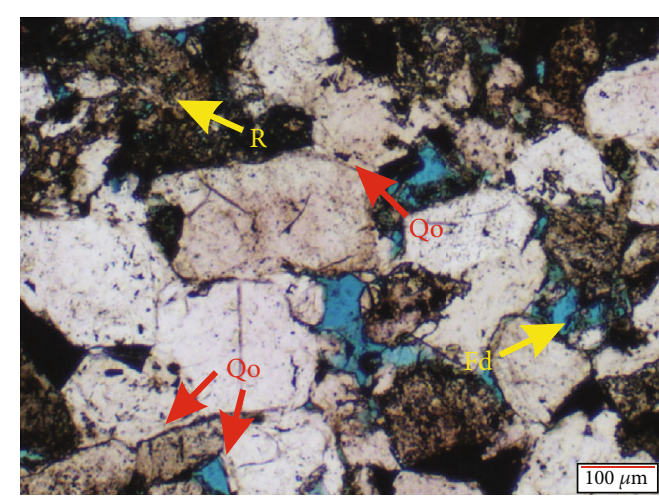

(b)

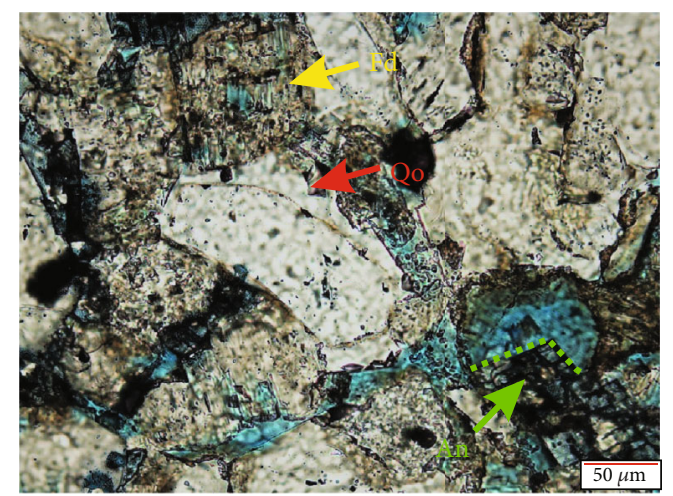

(d)

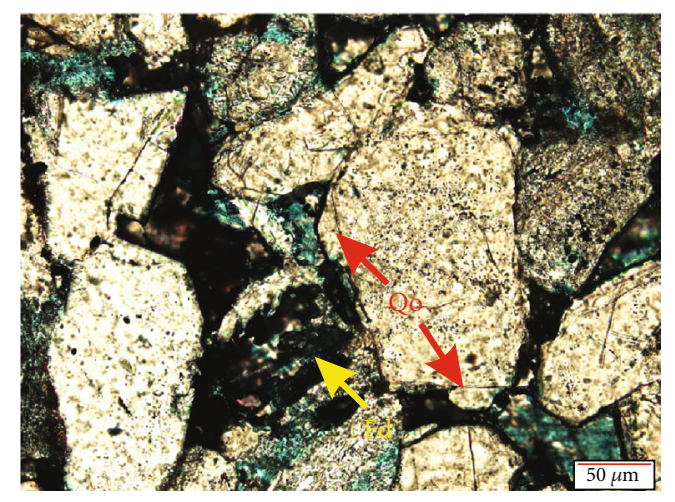

(f)

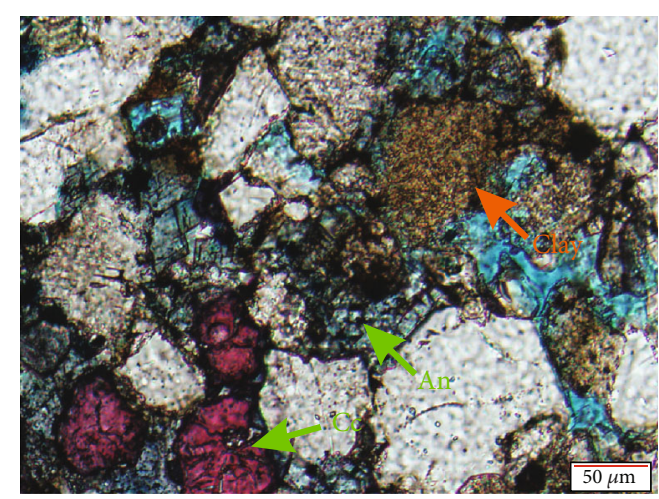

(h)

Figure 4: Continued. 


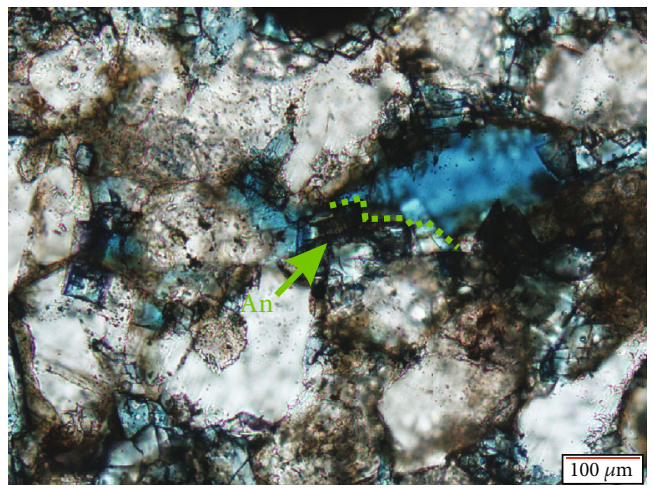

(i)

FIGURE 4: Photomicrographs of carbonate cements, dissolved feldspars and secondary minerals in thin sections. (a) F1, $3321.5 \mathrm{~m}$ : the dissolution of calcite and feldspar with the precipitation of secondary quartz; (b) F25, 2998.5 m: the leached feldspar and associated secondary minerals; (c) G351, 2444.5 m: feldspar dissolution and Fe-calcite and ankerite precipitation; (d) G351, 2447 m: the leached feldspar and associated secondary minerals, and the secondary intragranular pore is destroyed by ankerite precipitation; (e) F1, $3314.6 \mathrm{~m}$ : the precipitation of secondary quartz mineral with a width of approximate $40 \mu \mathrm{m}$; (f) F104, $3038.9 \mathrm{~m}$ : the leached feldspar and associated quartz overgrowths; (g) G891, $2808.4 \mathrm{~m}$ : early calcite cement and late ankerite cement; (h) G351, 2444.5 m: the dissolution of calcite and feldspar accompanied by clay minerals, and ankerite cement; (i) F1, $3319.1 \mathrm{~m}$ : the intergranular pores are destroyed by ankerite cements. Note: Qo: quartz overgrowth, R: rock fragment, Fd: feldspar dissolution, Cc: calcite, Fc: ferrocalcite, and An: ankerite.

(Figure 1(b)), which were partly stained with Alizarin red$\mathrm{S}$ and K-ferricyanide for petrographic and carbonate minerals observation under the Olympus BX51 microscope. 20 thin sections were selected for cathodoluminescence (CL) observation conducted by the LeicaDM2500P microscope with a voltage of $12 \mathrm{kV}$ and current of $250 \mu \mathrm{A}$. Four thin sections were coated by a Pt-conducting layer and then observed under a Zeiss Supra 55 field emission scanning electron microscope (SEM) with $20 \mathrm{kV}$ accelerating voltage. Secondary electron imaging and AsB detector were applied to characterize morphological features and reveal compositional difference, respectively. The SEM was equipped with energy-dispersive X-ray spectrometer (EDS) to analyse the elemental concentrations at a spot. Four doubly polished sections approximately $100 \mu \mathrm{m}$ thick were prepared for fluid inclusion measurement on quartz overgrowth and carbonate cements by a Linkam TH600 heating-freezing stage. Homogenization temperatures $\left(\mathrm{Th}\left({ }^{\circ} \mathrm{C}\right)\right.$ ) were measured for fluid inclusions using a heating rate of $25^{\circ} \mathrm{C} / \mathrm{min}$ at temperatures less than $70^{\circ} \mathrm{C}$ and a rate of 5 or $3^{\circ} \mathrm{C} / \mathrm{min}$ at temperatures exceeding $70^{\circ} \mathrm{C}$. The above-mentioned experiments were carried out at the State Key Laboratory of Geological Processes and Mineral Resources of China University of Geoscience (Beijing).

Porosity and permeability data of 588 core plugs $(2.5 \mathrm{~cm}$ diameter) and X-ray diffraction (XRD) data of 75 samples from the Shahejie sandstone reservoirs were collected from Shengli Oilfield Company, Sinopec. The porosity and permeability were analyzed using the $\mathrm{CMS}^{\mathrm{tm}}-300$ Core Measurement with $\mathrm{N}_{2}$ and a confining pressure of $6 \mathrm{MPa}$. The XRD analysis of the powdered samples (less than $40 \mathrm{~mm}$ ) was conducted by using a D/max-2500 theta/theta rotating anode X-ray diffractometer.
Four sandstone samples from wells F1, F25, G351, and F104 were cut into cubes of around $1 \mathrm{~cm}^{3}$ for highpressure mercury injection (HPMI) experiment at the Key Laboratory of Tectonics and Petroleum Resources of China University of Geosciences (Wuhan). These cubes were first oven dried at $60^{\circ} \mathrm{C}$ for over 48 hours to remove volatile substances and moisture and then cooled to room temperature (about $23^{\circ} \mathrm{C}$ ) in a desiccator. The experiment was conducted with the Autopore IV 9520 mercury injection instrument with a maximum pressure of $414 \mathrm{MPa}$.

The C-O isotopes, electron probe microanalysis (EPMA), and rare earth element (REE) of mudstone experiments were conducted on the Analytical Laboratory of the Research Institute of Uranium Geology (Beijing). Based on petrology observation, 13 carbonate-cemented sandstone samples were selected for carbon and oxygen isotope tests. Samples were drilled by a microdrill bit with a diameter of $2 \mathrm{~mm}$ for powder less than 200 meshes. Carbon and oxygen isotopes were measured by adding concentrated phosphoric acids to produce the $\mathrm{CO}_{2}$ which were tested by a MAT-253 gas isotope mass spectrometer. Isotopic compositions are reported in the standard delta notation as per mill (\%o) relative to Vienna Pee Dee Belemnite (VPDB), with an analytical precision of $\pm 0.2 \%$ o for carbon isotopes and $\pm 0.1 \%$ for oxygen isotopes.

EPMA was conducted for six samples by a JXA-8100 instrument at $20 \mathrm{kV}$ accelerating voltage, $1 \times 10^{-8} \mathrm{~A}$ beam current, and 3 to $5 \mu \mathrm{m}$ beam diameter. The major elements measured in the quartz overgrowth and carbonate include $\mathrm{Al}, \mathrm{Na}, \mathrm{Mg}, \mathrm{K}, \mathrm{Ca}, \mathrm{Sr}, \mathrm{Ni}, \mathrm{Ti}, \mathrm{Fe}, \mathrm{Cr}$, and $\mathrm{Mn}$.

The microdrilling samples of mudstones were analyzed for REE. About $25 \mathrm{mg}$ powder was dissolved by $1 \mathrm{~mL} \mathrm{HF}$ and $0.5 \mathrm{~mL} \mathrm{HNO}_{3}$ in a closed container, which was heated for 24 hours at about $185^{\circ} \mathrm{C}$ in an oven. Then, the container 


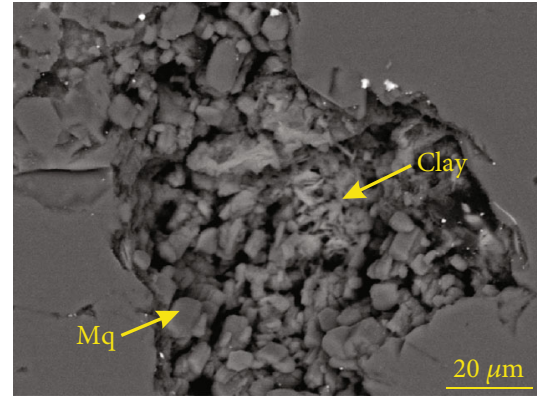

(a)

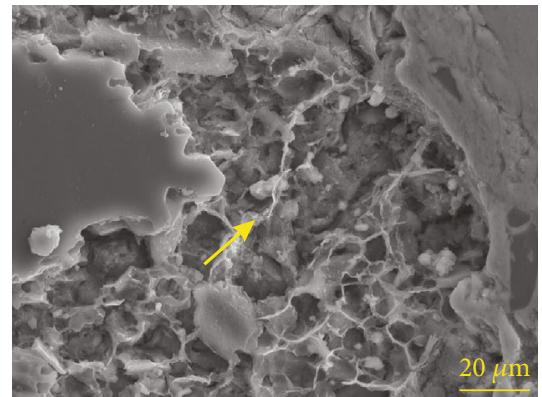

(c)

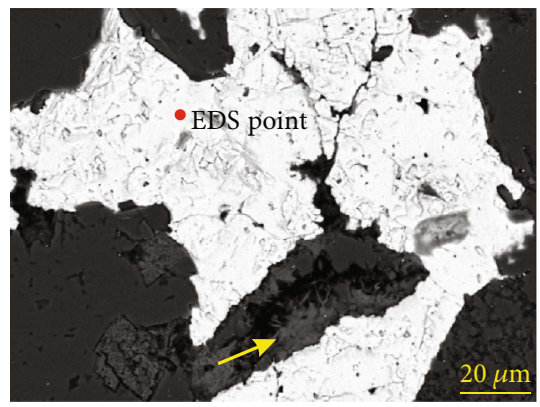

(e)

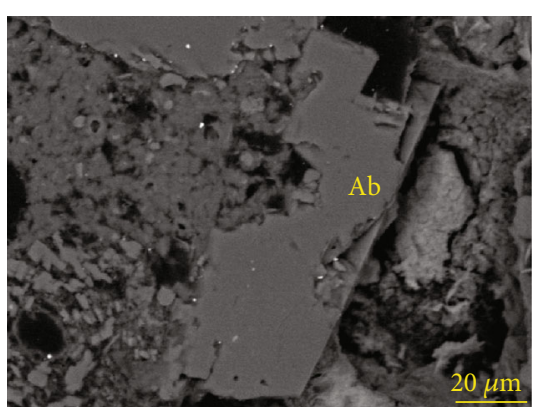

(b)

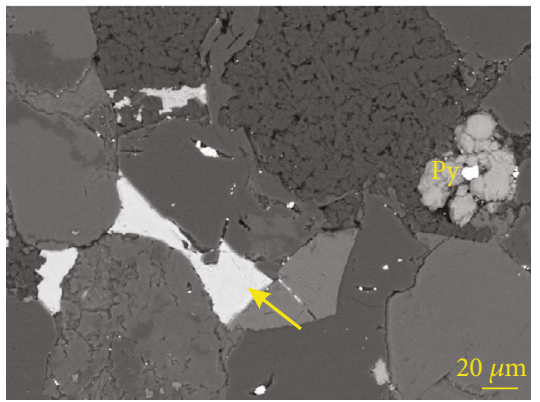

(d)

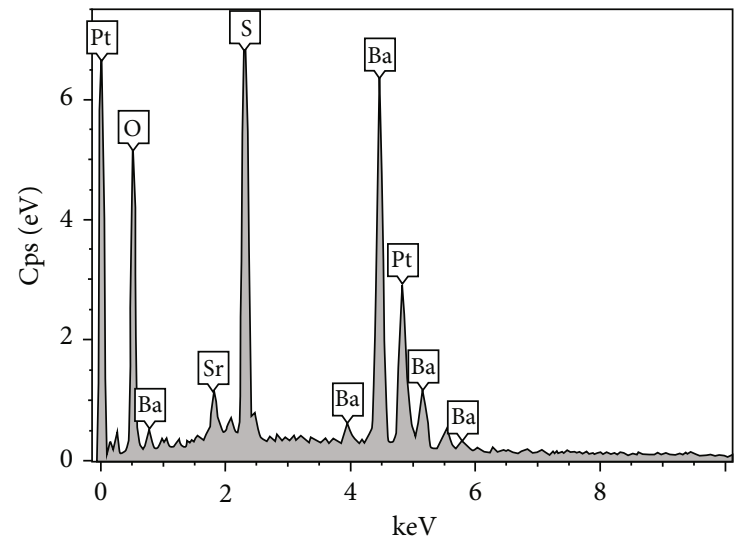

(f)

FIgURE 5: SEM-BSE images of beach-bar sandstones in the Boxing Sag. (a) F1, $3314.6 \mathrm{~m}$ : authigenic microquartz (Mq) and a few clay minerals; (b) F1, $3314.6 \mathrm{~m}$ : authigenic albite (Ab); (c) G351, $2455 \mathrm{~m}$ : the feldspar dissolution is accompanied by the precipitation of illite (yellow arrow); (d) G351, $2455 \mathrm{~m}$ : barite (yellow arrow) and pyrite (Py) are filled among particles; (e) F1, $3314.6 \mathrm{~m}$ : the leached detrital grain associated with chlorite (yellow arrow), and red spot represents an EDS analyzing point; (f) EDS-tested composition of the barite $\left(\mathrm{BaSO}_{4}\right)$.

was steamed to dry in an electric heating plate and added $0.5 \mathrm{~mL} \mathrm{HNO}_{3}$ to evaporate. This step was repeated once. After that, $5 \mathrm{~mL} \mathrm{HNO}_{3}$ was put into container and heated for 3 hours at $130^{\circ} \mathrm{C}$. Finally, the solution was transferred into a plastic bottle and diluted to $25 \mathrm{~mL}$ as well as measured through an Element XR inductively coupled plasma-mass spectrometry (ICP-MS).

The REE of carbonate cement experiments were carried out on Analytik Jena AG PlasmaQuant MS Plus, ICP-MS instrument, in combination with an excimer $193 \mathrm{~nm}$ laser ablation system (NWR193 UItra Compact). Each spot analysis consisted of approximately 30s background acquisition followed by 40 s data acquisition form the sample. Calibra- tion was performed using NIST SRM610 and 614as external calibrant in conjunction with internal standardization using $\mathrm{CaO}$. Data reduction was made using the GLITTER 4.0 software.

\section{Results}

4.1. Detrital Petrology. Petrographic investigation shows that the grain sizes of beach-bar sandstones mainly range between 0.021 and $0.421 \mathrm{~mm}$, of which the average $49.9 \%$ of the grains are $0.063-0.125 \mathrm{~mm}$ (very fine sand), $34.0 \%$ of the grains are $0.125-0.25 \mathrm{~mm}$ (fine sand), $7.5 \%$ of the grains are $0.25-0.50 \mathrm{~mm}$ (medium sand), and $7.4 \%$ of the 


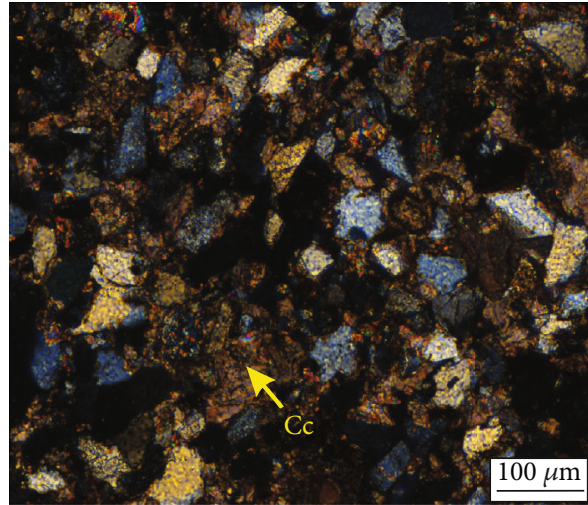

(a)

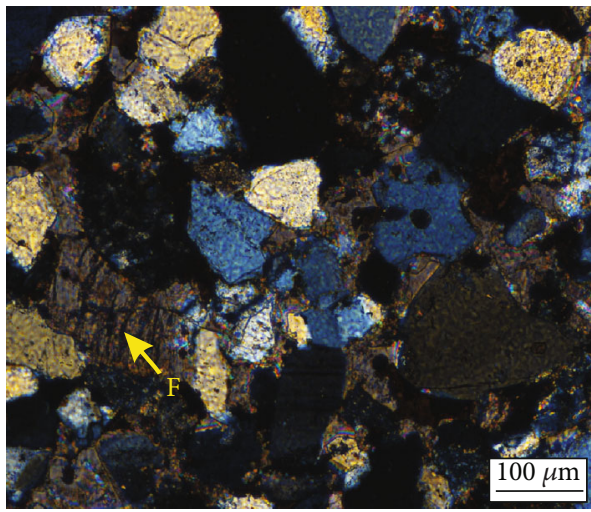

(c)

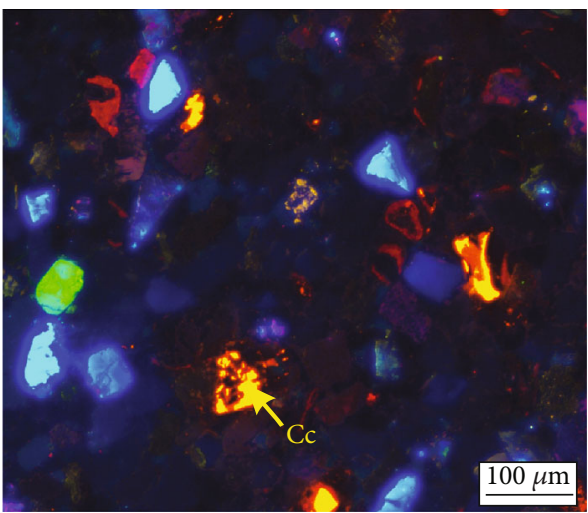

(b)

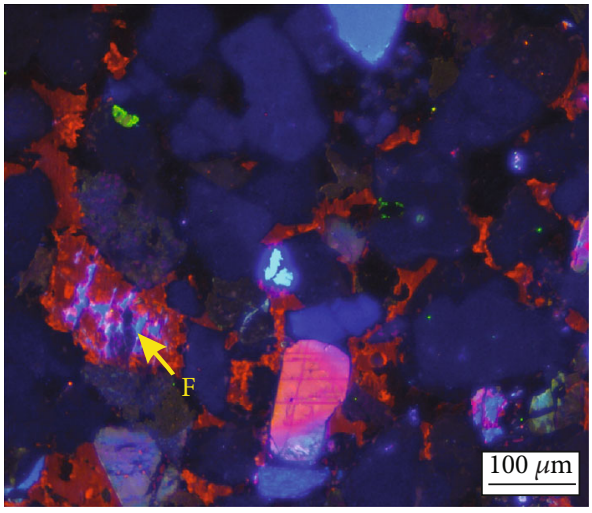

(d)

Figure 6: Cathodoluminescence (CL) observation of carbonate cements. (a, b) F1, 3319.1 m: calcite (Cc) and ankerite show the yellow and dark luminescence, respectively; (c, d) F104, 3059.4 m: the dissolution of feldspar (F) and Fe-calcite show the dark red luminescence.

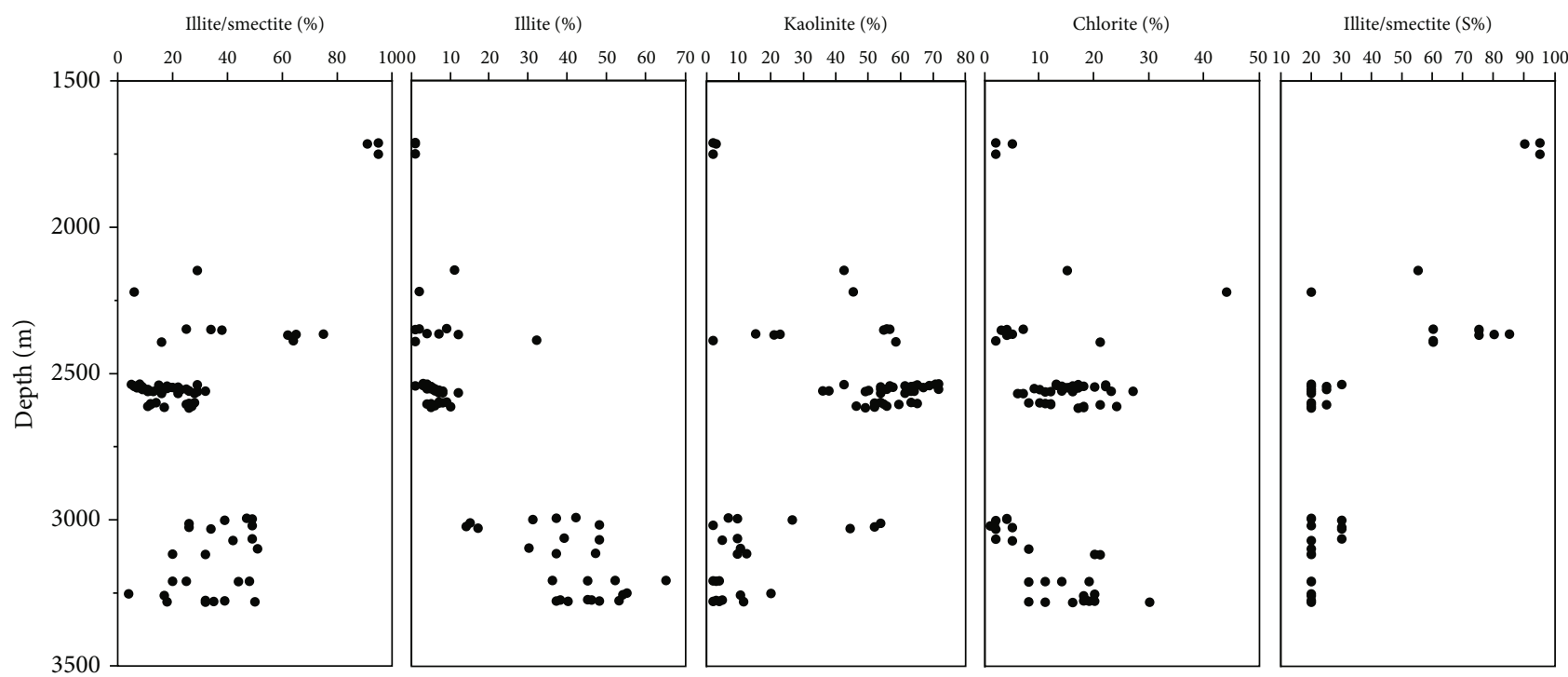

Figure 7: Vertical distribution characteristics of clay minerals in the Boxing Sag.

grains are $0.031-0.063 \mathrm{~mm}$ (coarse silt). Sorting ranges from medium to good sorted and roundness of the detrital particles are hypoedge angle for most of the sandstones (Table 1).

The detrital compositions of beach-bar sandstones comprise $39.4 \%-48.3 \%$ quartz (average $44.1 \%$ ), 14.4\%-17.9\% K- feldspars (average 16.4\%), 17.5-20.0\% plagioclase (average $19.1 \%$ ), and rock fragments $15.8 \%-26.7 \%$ (average $20.36 \%$ ) (Table 1). The rock fragments are mainly composed of volcanic rocks, metamorphic rocks, and a little sedimentary origin. The composition of sandstones is immature with an 


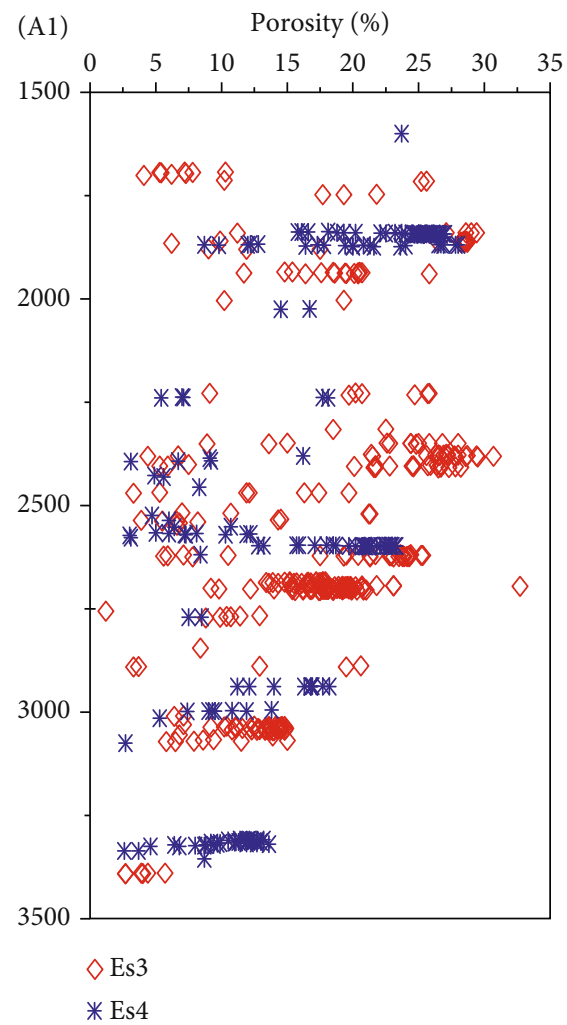

(A2) Permeability $(\mathrm{mD})$
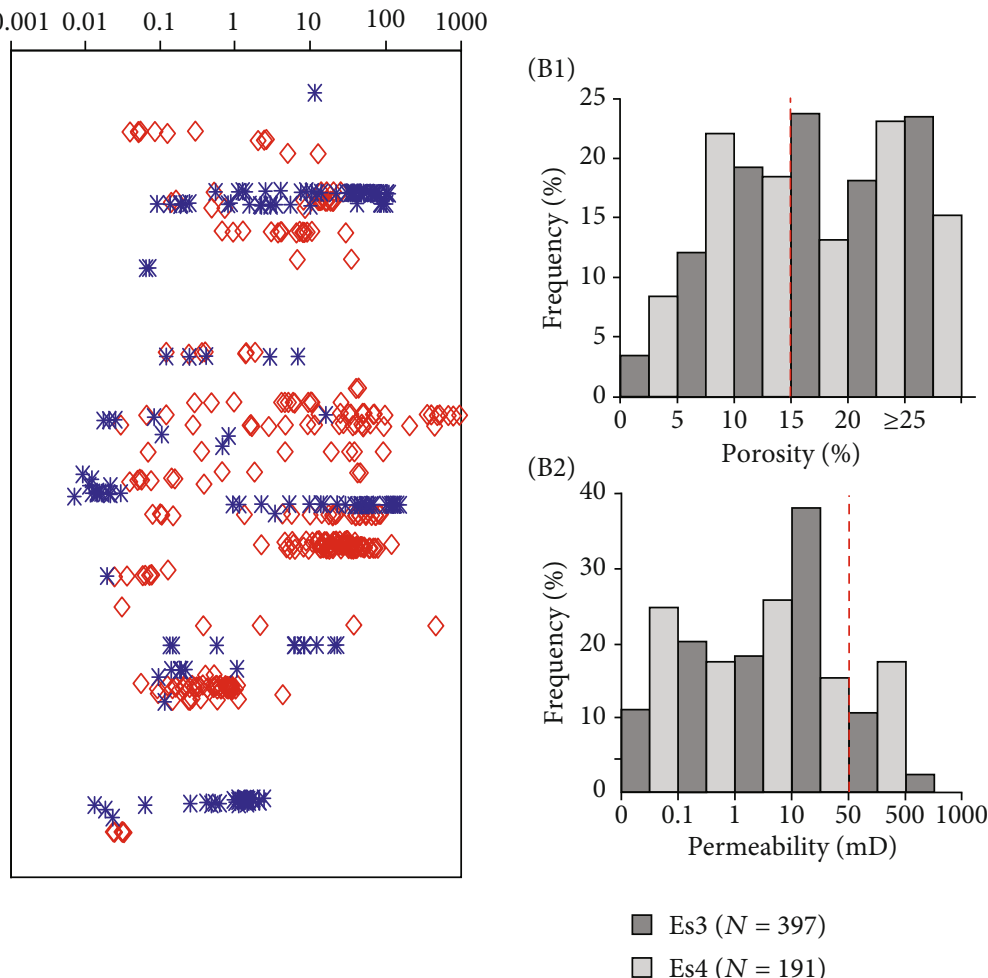

Figure 8: Petrophysical properties of sandstones in the Es3 and Es4 Formation in the Boxing Sag. (a, b) Vertical distribution of porosity and permeability. (c, d) Histogram distribution of porosity and permeability; the red dash lines distinguish low-porosity and low-permeability reservoirs.

average framework composition of $\mathrm{Q}_{44.1} \mathrm{~F}_{35.5} \mathrm{~L}_{20.4}$. Thus, beach-bar sandstones are mostly lithic arkoses based on the Folk [35] classification standard (Figure 3).

\subsection{Diagenetic Mineralogy}

4.2.1. Feldspar Diagenesis. Feldspars, including K-feldspars and plagioclases, were partly to fully dissolved in the beach-bar sandstones, which was associated with the precipitation of authigenic quartz and clay minerals (Figures 4(a) and 4(b)). The internal fabric of the partly dissolved feldspar could still be applied to distinguish among the composition of inherited minerals (Figures 4(b)-4(d)). On the whole, the secondary intragranular pores resulting from the dissolution of detrital feldspars as well as the primary intergranular pores were filled with newly formed minerals. Microscopy and SEM analysis showed that authigenic quartz mainly existed as quartz overgrowths and microquartz (Figures 4(e), 4(f), and 5(a)). The former was usually observed on the margin of quartz grains whose thickness could reach approximately $30 \mu \mathrm{m}$. Actually, quartz cements with exceptionally fine grains were difficult to identify in the sandstone (Figure 4(e)). A large number of microquartz crystals of only a few microns in size filled the gaps between the grains. Moreover, authigenic feldspar (albite) was also generated as overgrowths and well-crystallized grains under the SEM (Figure 5(b)), but it was not as common as authigenic quartz.

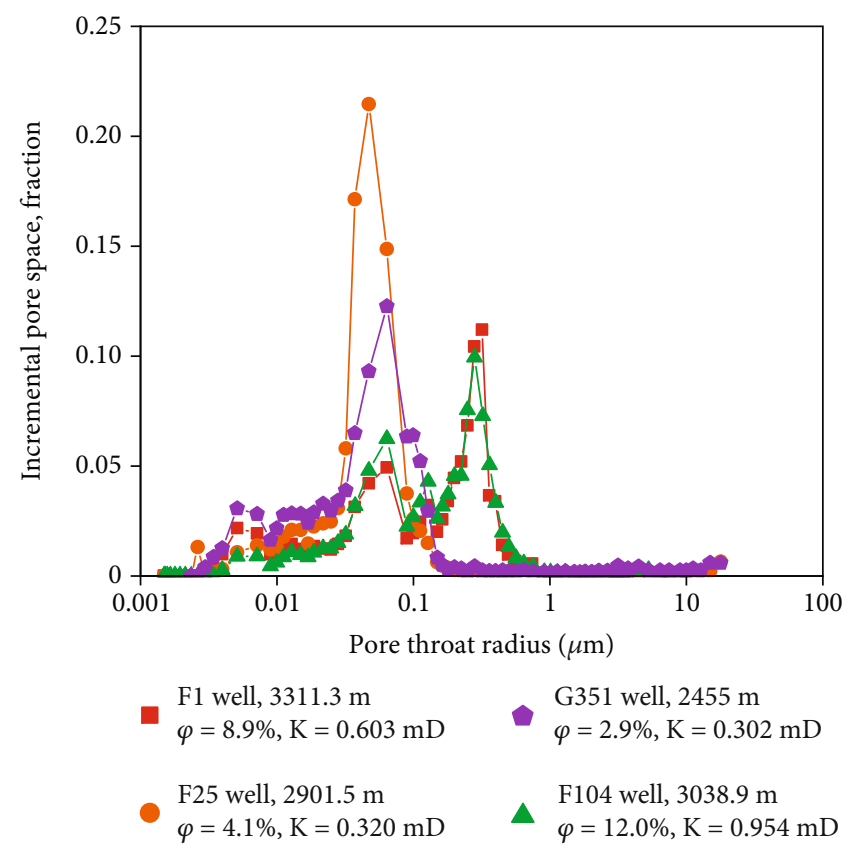

FIgURE 9: Typical pore throat radius distribution obtained from the HPMI experiment.

4.2.2. Carbonate Diagenesis. Three types of carbonate cements dominated by calcite, Fe-calcite, and ankerite could be distinguished in the sandstone reservoirs. Different types 


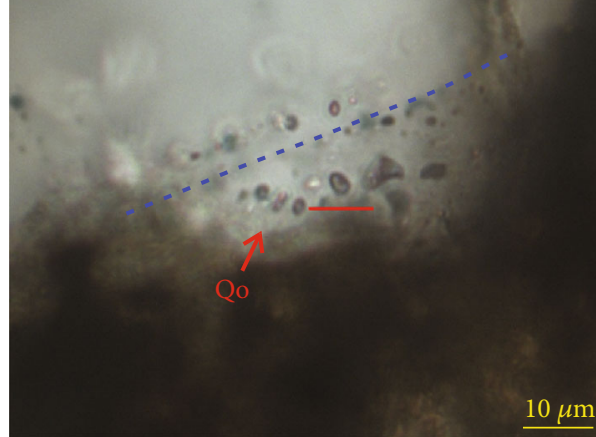

(a)

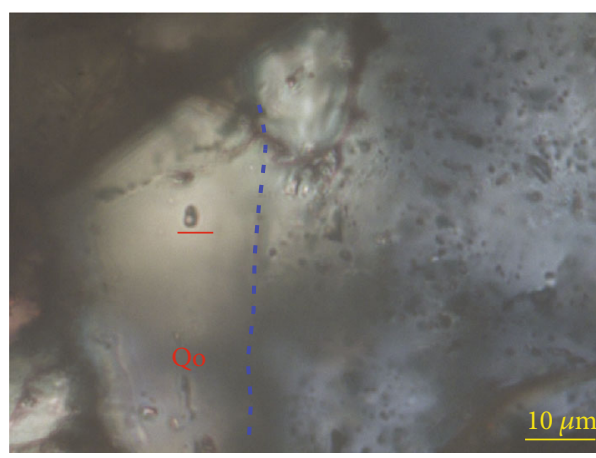

(c)

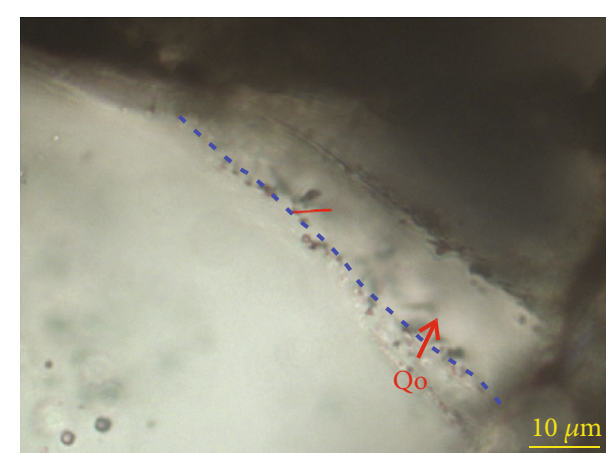

(b)

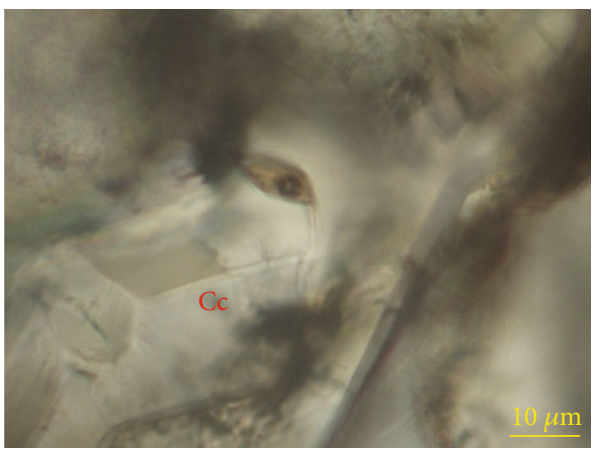

(d)

Figure 10: Petrography of fluid inclusions within quartz overgrowths (Qo) and carbonate cementation (Cc) in sandstones.

of carbonate cements could be formed in different periods during the diagenesis process and indicate the pore water characteristics. Calcites occupied the primary pore spaces among clastic grains, displayed the dissolved feature, and showed yellow luminescence (Figures 4(g), 4(f), 6(a), and 6(b)). Generally, sandstones containing calcite cements were normally supported by clastic grains with point contacts or exhibited floating structures (Figure 4(h)). Fecalcites with dark red luminescence filled the intergranular pores and secondary intragranular pores of the dissolved feldspars (Figures 4(c), 6(c), and 6(d)). Ankerites with dark luminescence occupied the intergranular pores and exhibited euhedral rhombs growing in the dissolved feldspar pores and replacing the preexisting calcite (Figures 4(d), $4(\mathrm{~h})$, and $4(\mathrm{i}))$.

4.2.3. Clay and Other Minerals. The observation conducted on thin sections showed that feldspar dissolution was accompanied with clay mineral precipitation. SEM analysis revealed the presence of clay minerals with fibrous and flaky features in feldspar dissolution pores and grew together with minor amounts of microcrystalline authigenic quartz (Figures 5(a) and 5(c)). Needle-shaped chlorite could be observed in the dissolved pores (Figure 5(e)). X-ray diffraction data of bulk rocks showed that the mixed-layer illite/ smectite and kaolinite, followed by illite and chlorite, are the clay minerals found in majority in the Boxing sandstone reservoirs (Figure 7). The content of mixed-layer illite/smectite decreased at 1750 to $2600 \mathrm{~m}$ and then increased from 2600 to $3250 \mathrm{~m}$. However, the mixed-layer ratio ( $\mathrm{S} \%$ in I/S) apparently decreased as the depth increased. The content of kaolinite increased at 1750 to $2600 \mathrm{~m}$ and decreased at 2600 to $3250 \mathrm{~m}$ as the depth increased. The content of chlorite did not exceed $25 \%$ and hardly varied in the vertical distribution.

Besides, barite $\left(\mathrm{BaSO}_{4}\right)$ exhibiting an irregular shape filled among the clastic grain gaps and could be identified via the SEM-EDS analysis in the wells F1 and G351 (Figures 5(d)-5(f)). Pyrite comprised of nodule-shaped aggregates and occurred as a variant of pore-filling cement (Figure 5(d)).

4.3. Petrophysical Characteristics. The Shahejie Formation sandstone samples in the Boxing Sag exhibited widely distributed porosity and permeability ranging from $1.2 \%$ to $32.7 \%$ and from 0.023 to $1276 \mathrm{mD}$ as well as from $2.6 \%$ to $28.0 \%$ and from 0.007 to $152.28 \mathrm{mD}$, respectively. Generally, the sample porosity and permeability decreased as the burial depth increased from 1500 to $3500 \mathrm{~m}$ (Figures 8(a) and $8(b))$. Based on the reservoir classification from Zeng and Li [36], 34.8\% and $48.7 \%$ of the Es3 and Es4 sandstones, respectively, were low-porosity reservoirs; their porosity was less than $15.0 \%$ (Figure $8(\mathrm{c})$ ); $87.2 \%$ and $82.7 \%$ of the Es3 and Es4 sandstones, respectively, were lowpermeability reservoirs; their permeability was less than $50.0 \mathrm{mD}$ (Figure $8(\mathrm{~d})$ ).

The high-pressure mercury intrusion (HPMI) analysis of four beach-bar sandstone samples also satisfied the characteristics of low-porosity and low-permeability sandstone reservoirs. In particular, the permeability was usually less than 
TABLE 2: Microthermometric data of fluid inclusions in the authigenic minerals.

\begin{tabular}{lccccccccc}
\hline Well & Depth $(\mathrm{m})$ & Strata & Host mineral & Th $\left({ }^{\circ} \mathrm{C}\right)$ & Well & Depth $(\mathrm{m})$ & Strata & Host mineral & Th $\left({ }^{\circ} \mathrm{C}\right)$ \\
\hline F25 & 2998.5 & Es3 & Qo & 113 & F182 & 3109.5 & Es3 & Qo & 115.7 \\
F25 & 2998.5 & Es3 & Qo & 129 & F182 & 3109.5 & Es3 & Qo & Qo \\
F25 & 2998.5 & Es3 & Qo & 117 & F182 & 3109.5 & Es3 & 111.1 \\
F25 & 2998.5 & Es3 & Qo & 116 & G351 & 2444.45 & Es4 & Qo & 106 \\
F25 & 2998.5 & Es3 & Qo & 116 & G351 & 2444.45 & Es4 & Qo \\
F104 & 3038.9 & Es3 & Qo & 110 & G351 & 2444.45 & Es4 & Qo \\
F104 & 3038.9 & Es3 & Qo & 115 & G351 & 2444.45 & Es4 & Qo \\
F104 & 3038.9 & Es3 & Qo & 120 & G351 & 2444.45 & Es4 & Qo & 115 \\
F104 & 3038.9 & Es3 & Qo & 109 & G351 & 2444.45 & Es4 & Qo \\
F104 & 3038.9 & Es3 & Qo & 99 & F25 & 2998.5 & Es3 & Cc \\
F104 & 3038.9 & Es3 & Qo & 102 & F25 & 2998.5 & Es3 & Cc \\
F104 & 3038.9 & Es3 & Qo & 111 & F25 & 2998.5 & Es3 & Cc \\
F182 & 3109.5 & Es3 & Qo & 124.1 & F25 & 2998.5 & Es3 & Cc \\
F182 & 3109.5 & Es3 & Qo & 108.3 & F25 & 2998.5 & Es3 & Cc \\
F182 & 3109.5 & Es3 & Qo & 120.7 & F104 & 3038.9 & Es3 & Cc \\
F182 & 3109.5 & Es3 & Qo & 117.9 & F104 & 3038.9 & Es3 & Cc
\end{tabular}

Qo: quartz overgrowth; Cc: carbonate cementation.

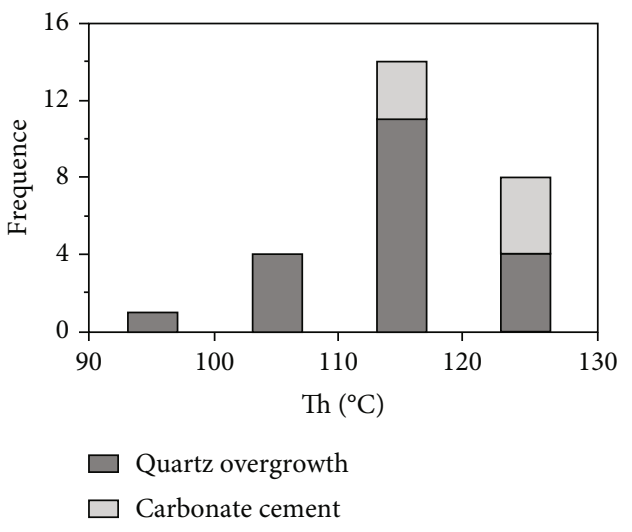

(a)

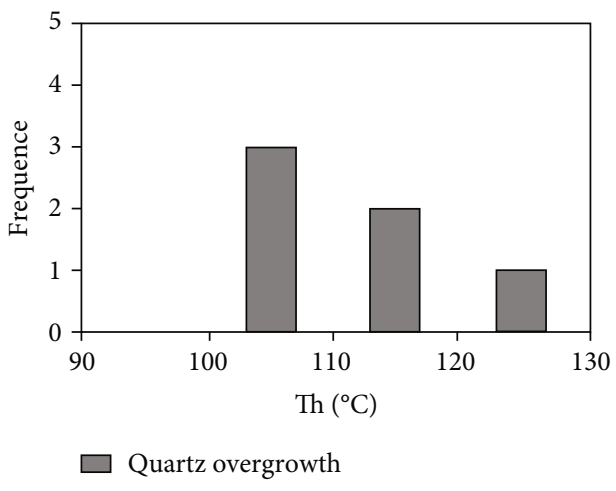

(b)

Figure 11: Histogram of Th for fluid inclusions in the quartz overgrowths and carbonate cements. (a) Es3 Formation; (b) Es4 Formation.

$1 \mathrm{mD}$. The distribution of pore throat radius mainly ranged between 0.01 and $1 \mu \mathrm{m}$ depending on the micropore size (Figure 9).

4.4. Fluid Inclusions. Fluid inclusions in authigenic minerals (quartz overgrowth and carbonate) could provide information about the diagenetic environment. Nevertheless, quartz overgrowths could not be easily identified as the grain sizes were dominated by very fine sand in certain wells, and the size of two-phase fluid inclusions in the quartz overgrowths was mainly less than $6 \mu \mathrm{m}$ (Figures $10(\mathrm{a})-10(\mathrm{c})$ ). Together, these factors posed great challenges to the measurement of the homogenization temperature. Herein, the adjacent wells and samples of similar depth were selected for measuring the $\mathrm{Th}\left({ }^{\circ} \mathrm{C}\right)$ of aqueous inclusions (Table 2$)$. The Th $\left({ }^{\circ} \mathrm{C}\right)$ of quartz overgrowths mainly ranged between $99^{\circ} \mathrm{C}$ and $129^{\circ} \mathrm{C}$ in the Es3x Formation (Figure $\left.11(\mathrm{a})\right)$. The Th $\left({ }^{\circ} \mathrm{C}\right)$ from well $\mathrm{G} 351$ ranged between $106^{\circ} \mathrm{C}$ and $121^{\circ} \mathrm{C}$ in the Es4s Formation (Figure 11(b)). Meanwhile, the fluid inclusions within carbonate cements of wells F104 and F25 were extremely small and rarely found. The Th $\left({ }^{\circ} \mathrm{C}\right)$ mainly ranged between $118^{\circ} \mathrm{C}$ and $126^{\circ} \mathrm{C}$ in the Es3 Formation (Figures 10(d) and 11(a)).

4.5. Geochemical Characteristics. The carbon and oxygen isotopic compositions of carbonate cements in the Es4 Formation sandstones show that the $\delta^{18} \mathrm{O}$ values range between $-11.7 \%$ and $-8.4 \%$, and the $\delta^{13} \mathrm{C}$ values range between $-1.7 \%$ and $-0.5 \%$. The isotopic $\delta^{18} \mathrm{O}$ and $\delta^{13} \mathrm{C}$ values of carbonate cements in the Es3x Formation sandstone range 
TABle 3: Mineralogical and isotopic composition of carbonate. Ca: calcite; Fc: Fe-calcite; An: ankerite.

\begin{tabular}{|c|c|c|c|c|c|c|c|}
\hline Well & Lithology & Depth & Strata & Carbonate content & Minerals & $\delta^{18} \mathrm{O}_{-\mathrm{PDB}}(\% \mathrm{o})$ & $\delta^{13} \mathrm{C}_{-\mathrm{PDB}}(\% \mathrm{o})$ \\
\hline F1 & Sandstone & 3321.5 & Es4 & $14.2 \%$ & $70 \% \mathrm{An}+30 \% \mathrm{Ca}$ & -11.3 & -0.8 \\
\hline F1 & Sandstone & 3319.1 & Es4 & $13.6 \%$ & $100 \%$ An & -9.6 & -0.5 \\
\hline F1 & Sandstone & 3314.6 & Es4 & $7.4 \%$ & $80 \% \mathrm{An}+20 \% \mathrm{Ca}$ & -11.7 & -1.1 \\
\hline $\mathrm{F} 1$ & Sandstone & 3312.3 & Es4 & $8.9 \%$ & $80 \% \mathrm{An}+20 \% \mathrm{Ca}$ & -11.4 & -1.2 \\
\hline $\mathrm{F} 1$ & Sandstone & 3310.3 & Es4 & $3.4 \%$ & $100 \%$ An & -10 & -0.8 \\
\hline $\mathrm{F} 1$ & Sandstone & 3311.3 & Es4 & $3.7 \%$ & $100 \%$ An & -10.3 & -1 \\
\hline G893 & Sandstone & 3210.2 & Es4 & - & $95 \% \mathrm{An}+5 \% \mathrm{Ca}$ & -8.4 & -0.3 \\
\hline G893 & Sandstone & 3281.0 & Es4 & $25.1 \%$ & $90 \% \mathrm{An}+10 \% \mathrm{Ca}$ & -9.3 & -1.7 \\
\hline F31 & Sandstone & 2934.0 & Es3 & $4.6 \%$ & $100 \% A n$ & -12.1 & 3 \\
\hline F25 & Sandstone & 2901.5 & Es3 & $10.2 \%$ & $90 \% \mathrm{Fc}+10 \% \mathrm{Ca}$ & -12.8 & 3.3 \\
\hline $\mathrm{F} 25$ & Sandstone & 2998.5 & Es3 & $2.8 \%$ & $90 \% \mathrm{Fc}+10 \% \mathrm{Ca}$ & -13.8 & 1.6 \\
\hline F104 & Sandstone & 3038.9 & Es3 & $16.2 \%$ & $95 \% \mathrm{An}+5 \% \mathrm{Fc}$ & -13.4 & 3.3 \\
\hline F104 & Sandstone & 3039.2 & Es3 & $14.1 \%$ & $95 \% \mathrm{An}+5 \% \mathrm{Fc}$ & -9.5 & 2.9 \\
\hline
\end{tabular}

TABLE 4: Electronic probe microanalysis for quartz in the Es3 sandstone (wt\%).

\begin{tabular}{|c|c|c|c|c|c|c|c|c|c|c|c|c|c|}
\hline Well & Depth $(\mathrm{m})$ & Point & $\mathrm{MgO}$ & $\mathrm{Na}_{2} \mathrm{O}$ & $\mathrm{FeO}$ & $\mathrm{CaO}$ & $\mathrm{Al}_{2} \mathrm{O}_{3}$ & $\mathrm{MnO}$ & $\mathrm{K}_{2} \mathrm{O}$ & $\mathrm{SrO}$ & $\mathrm{TiO}_{2}$ & $\mathrm{SiO}_{2}$ & Total \\
\hline \multirow{7}{*}{ F31 } & \multirow{6}{*}{2934.0} & Q & 0 & 0 & 0.03 & 0.02 & 0 & 0.02 & 0 & 0.33 & 0 & 99.3 & 99.7 \\
\hline & & Qo & 0 & 0.03 & 0.02 & 0.03 & 0.14 & 0 & 0 & 0.33 & 0.02 & 98.6 & 99.17 \\
\hline & & Qo & 0 & 0 & 0 & 0.05 & 0.17 & 0 & 0 & 0.27 & 0 & 98.4 & 98.89 \\
\hline & & $\mathrm{Q}$ & 0 & 0 & 0.02 & 0 & 0.07 & 0 & 0.03 & 0.34 & 0.02 & 99.26 & 99.74 \\
\hline & & Qo & 0 & 0 & 0 & 0.05 & 0.14 & 0 & 0.02 & 0.29 & 0.02 & 99.23 & 99.75 \\
\hline & & Qo & 0 & 0 & 0 & 0.02 & 0.05 & 0 & 0.01 & 0.29 & 0.04 & 99.03 & 99.44 \\
\hline & \multirow{3}{*}{2998.5} & $\mathrm{Q}$ & 0.03 & 0.02 & 0 & 0 & 0 & 0 & 0 & 0.27 & 0.04 & 99.46 & 99.82 \\
\hline \multirow[t]{2}{*}{ F25 } & & Qo & 0.02 & 0 & 0.04 & 0.11 & 0.19 & 0 & 0 & 0.36 & 0 & 98.58 & 99.3 \\
\hline & & Qo & 0.05 & 0 & 0 & 0.25 & 0.2 & 0 & 0.02 & 0.37 & 0 & 98.38 & 99.27 \\
\hline \multirow{6}{*}{ F104 } & \multirow{6}{*}{3039.2} & $\mathrm{Q}$ & 0.02 & 0.04 & 0 & 0.04 & 0.04 & 0 & 0 & 0.36 & 0 & 99.53 & 100.03 \\
\hline & & Qo & 0 & 0.02 & 0 & 0.03 & 0.18 & 0 & 0 & 0.29 & 0 & 98.9 & 99.42 \\
\hline & & Qo & 0 & 0 & 0 & 0.08 & 0.09 & 0.03 & 0 & 0.35 & 0 & 98.64 & 99.19 \\
\hline & & $\mathrm{Q}$ & 0 & 0.03 & 0 & 0 & 0.02 & 0 & 0 & 0.29 & 0 & 99.19 & 99.53 \\
\hline & & Qo & 0 & 0 & 0 & 0.02 & 0.17 & 0 & 0 & 0.35 & 0 & 98.8 & 99.34 \\
\hline & & Qo & 0 & 0.04 & 0.02 & 0.05 & 0.12 & 0 & 0.02 & 0.3 & 0 & 99.16 & 99.71 \\
\hline
\end{tabular}

between $-12.8 \%$ and $-9.5 \%$ and between $1.6 \%$ and $3.3 \%$, respectively (Table 3 ).

The EPMA analysis was conducted to investigate the chemical differences between detrital and authigenic quartz as well as carbonate cements. The results obtained from this analysis of quartz particles showed that $\mathrm{CaO}$ and $\mathrm{Al}_{2} \mathrm{O}_{3}$ were slightly enriched in authigenic quartz content compared with the detrital phase. Moreover, the chemical compositions of quartz overgrowths at the inner and outer points exhibited no obvious differences (Table 4). The calcite normally displayed a high content in $\mathrm{MnO}$. Fe-calcite and ankerite always had higher content of $\mathrm{FeO}$ and/or $\mathrm{MgO}$ and a slightly higher content of $\mathrm{SrO}, \mathrm{Na}_{2} \mathrm{O}, \mathrm{Al}_{2} \mathrm{O}_{3}$, and $\mathrm{K}_{2} \mathrm{O}$ than calcite (Table 5).

The REE data of carbonate cements and mudstones are shown in Table 6, displaying a high content of light REE
(LREE) and a low content of heavy REE (HREE). The REE concentrations have been normalized by chondrite from Boynton [37] and given the subscript $N$. The $\delta \mathrm{Ce}$ and $\delta \mathrm{Eu}$ values are calculated by $2 \mathrm{Ce}_{N} /\left(\mathrm{La}_{N}+\mathrm{Pr}_{N}\right)$ and $2 \mathrm{Eu}_{N} /\left(\mathrm{Sm}_{N}\right.$ $\left.+\mathrm{Gd}_{N}\right)$, respectively. The $\delta \mathrm{Ce}$ value of carbonate cement and mudstone ranged from 0.38 to 1.08 and from 0.87 to 0.94 , with average values of 0.81 and 0.90 , respectively. The $\delta \mathrm{Eu}$ value of carbonate cement ranged between 0.14 and 2.63 , with an average value of 1.10 . It had a relatively wider distribution than that of mudstone whose $\delta \mathrm{Eu}$ value ranged between 0.51 and 0.61 .

\section{Discussions}

5.1. Diagenetic Sequences. The diagenetic processes of beachbar sandstone reservoirs can be elucidated by investigating 
TABLE 5: Electronic probe microanalysis for carbonate cements in the sandstone (wt\%).

\begin{tabular}{|c|c|c|c|c|c|c|c|c|c|c|c|c|c|}
\hline Well & Depth (m) & $\mathrm{MgO}$ & $\mathrm{Na}_{2} \mathrm{O}$ & $\mathrm{FeO}$ & $\mathrm{CaO}$ & $\mathrm{Al}_{2} \mathrm{O}_{3}$ & $\mathrm{MnO}$ & $\mathrm{K}_{2} \mathrm{O}$ & $\mathrm{SrO}$ & $\mathrm{TiO}_{2}$ & $\mathrm{Cr}_{2} \mathrm{O}_{3}$ & $\mathrm{CO}_{2}$ & Total \\
\hline \multirow{4}{*}{$\mathrm{F} 1$} & \multirow{4}{*}{3314.6} & 0.27 & 0.00 & 0.16 & 53.89 & 0.03 & 1.44 & 0.00 & 0.04 & 0.00 & 0.00 & 43.67 & 99.50 \\
\hline & & 0.25 & 0.00 & 0.14 & 53.58 & 0.03 & 1.65 & 0.00 & 0.00 & 0.03 & 0.00 & 43.52 & 99.20 \\
\hline & & 8.99 & 0.00 & 15.06 & 30.89 & 0.04 & 0.54 & 0.02 & 0.10 & 0.00 & 0.00 & 43.73 & 99.37 \\
\hline & & 8.44 & 0.03 & 16.69 & 30.24 & 0.02 & 0.40 & 0.00 & 0.00 & 0.03 & 0.00 & 43.49 & 99.34 \\
\hline \multirow{4}{*}{ F1 } & \multirow{4}{*}{3311.3} & 0.39 & 0.00 & 1.70 & 53.61 & 0.02 & 0.36 & 0.15 & 0.11 & 0.00 & 0.00 & 43.91 & 100.25 \\
\hline & & 0.29 & 0.02 & 0.05 & 54.50 & 0.06 & 0.70 & 0.00 & 0.00 & 0.00 & 0.00 & 43.67 & 99.29 \\
\hline & & 8.62 & 0.13 & 16.31 & 30.77 & 0.00 & 0.27 & 0.04 & 0.03 & 0.00 & 0.00 & 43.87 & 100.04 \\
\hline & & 8.98 & 0.00 & 14.29 & 31.78 & 0.04 & 0.42 & 0.06 & 0.27 & 0.00 & 0.02 & 44.00 & 99.86 \\
\hline \multirow{2}{*}{ F31 } & \multirow{2}{*}{2934} & 9.03 & 0.03 & 13.56 & 32.69 & 0.00 & 0.35 & 0.03 & 0.25 & 0.00 & 0.00 & 44.20 & 100.14 \\
\hline & & 9.54 & 0.03 & 13.21 & 32.02 & 0.00 & 0.37 & 0.00 & 0.11 & 0.03 & 0.00 & 43.99 & 99.30 \\
\hline \multirow{4}{*}{ F25 } & \multirow{4}{*}{2998.5} & 0.21 & 0.03 & 0.53 & 54.79 & 0.00 & 0.03 & 0.03 & 0.00 & 0.00 & 0.02 & 43.66 & 99.30 \\
\hline & & 0.16 & 0.00 & 0.51 & 54.70 & 0.03 & 0.03 & 0.02 & 0.00 & 0.00 & 0.02 & 43.50 & 98.97 \\
\hline & & 0.34 & 0.10 & 2.21 & 52.84 & 0.04 & 0.22 & 0.00 & 0.00 & 0.00 & 0.00 & 43.74 & 99.49 \\
\hline & & 0.26 & 0.09 & 1.75 & 53.17 & 0.03 & 0.28 & 0.01 & 0.00 & 0.02 & 0.00 & 43.58 & 99.18 \\
\hline \multirow{2}{*}{ F25 } & \multirow{2}{*}{2901.5} & 0.54 & 0.00 & 1.92 & 53.55 & 0.18 & 0.17 & 0.00 & 0.00 & 0.00 & 0.00 & 44.25 & 100.61 \\
\hline & & 0.54 & 0.04 & 2.56 & 52.81 & 0.02 & 0.20 & 0.02 & 0.00 & 0.00 & 0.00 & 43.83 & 100.01 \\
\hline \multirow{7}{*}{ F104 } & \multirow{7}{*}{3038.9} & 9.02 & 0.00 & 15.50 & 30.84 & 0.17 & 0.20 & 0.07 & 0.22 & 0.00 & 0.02 & 44.12 & 100.16 \\
\hline & & 0.47 & 0.18 & 1.32 & 52.70 & 0.07 & 0.14 & 0.07 & 0.79 & 0.00 & 0.00 & 43.36 & 99.10 \\
\hline & & 0.37 & 0.19 & 1.25 & 53.55 & 0.05 & 0.14 & 0.03 & 0.77 & 0.00 & 0.00 & 43.85 & 100.20 \\
\hline & & 0.35 & 0.00 & 1.24 & 53.30 & 0.05 & 0.12 & 0.00 & 0.76 & 0.00 & 0.00 & 43.44 & 99.26 \\
\hline & & 0.68 & 0.10 & 1.21 & 52.51 & 0.08 & 0.11 & 0.09 & 0.86 & 0.00 & 0.00 & 43.35 & 98.99 \\
\hline & & 0.69 & 0.04 & 1.13 & 53.30 & 0.08 & 0.12 & 0.06 & 0.74 & 0.00 & 0.00 & 43.86 & 100.02 \\
\hline & & 9.15 & 0.00 & 12.71 & 32.97 & 0.00 & 0.34 & 0.00 & 0.28 & 0.00 & 0.00 & 44.02 & 99.47 \\
\hline \multirow{2}{*}{ F104 } & \multirow{2}{*}{3039.2} & 0.39 & 0.00 & 1.62 & 53.49 & 0.02 & 0.24 & 0.00 & 0.10 & 0.00 & 0.00 & 43.62 & 99.48 \\
\hline & & 0.31 & 0.04 & 1.42 & 53.84 & 0.00 & 0.17 & 0.13 & 0.22 & 0.00 & 0.00 & 43.76 & 99.89 \\
\hline
\end{tabular}

TABLE 6: The REE data of carbonate cement and mudstone ( $\mu \mathrm{g} / \mathrm{g})$.

\begin{tabular}{|c|c|c|c|c|c|c|c|c|c|c|c|c|c|c|c|c|c|c|}
\hline \multirow{2}{*}{$\frac{\mathrm{REE}}{\mathrm{La}}$} & \multicolumn{3}{|c|}{$\begin{array}{c}\text { F25: } 2901.5 \mathrm{~m} \\
(\mathrm{n}=3)\end{array}$} & \multicolumn{4}{|c|}{$\begin{array}{c}\text { F25: } 2998.5 \mathrm{~m} \\
(\mathrm{n}=4)\end{array}$} & \multicolumn{4}{|c|}{$\begin{array}{c}\text { F104: } 3039.2 \mathrm{~m} \\
\quad(\mathrm{n}=4)\end{array}$} & \multicolumn{3}{|c|}{$\begin{array}{c}\text { F104: } 3059.4 \mathrm{~m} \\
\quad(\mathrm{n}=3)\end{array}$} & \multicolumn{4}{|c|}{$\begin{array}{l}\text { F1: mudstone } \\
\quad(\mathrm{n}=4)\end{array}$} \\
\hline & 20.19 & 3.10 & 36.07 & 2.83 & 2.20 & 6.37 & 6.81 & 8.14 & 0.76 & 6.99 & 5.28 & 6.02 & 9.19 & 28.11 & 49.30 & 52.30 & 48.10 & 55.60 \\
\hline $\mathrm{Ce}$ & 34.74 & 5.03 & 60.58 & 43 & 1.73 & 17.27 & & 13.30 & 0.95 & & & 13.19 & & 9.12 & & .10 & 4.00 & 4.90 \\
\hline $\operatorname{Pr}$ & 4.43 & 0.78 & 4.93 & 0.80 & 0.21 & 2.45 & 2.77 & 1.45 & 0.06 & & & 2.00 & 33 & 3.60 & & 11.40 & 22 & 1.10 \\
\hline $\mathrm{Nd}$ & 17.78 & 3.45 & 13.68 & 4.39 & 1.05 & 10.41 & 13. & 5.31 & 0.20 & & & 9.90 & 3 & 79 & & 45.80 & 3.40 & 2.80 \\
\hline $\mathrm{Sm}$ & 3.79 & 0.67 & 4.50 & 1.14 & 0.43 & 2.90 & 4.12 & 0.59 & 0.05 & 0.17 & 0.44 & 2.97 & 0.47 & 1.38 & 6.93 & 7.55 & 4.66 & 6.30 \\
\hline $\mathrm{Eu}$ & 1.41 & 0.12 & 1.12 & 0.38 & 0.26 & 0.54 & 1.19 & 0.43 & 0.00 & 0.24 & 0.10 & 0.91 & 0.18 & 0.39 & 1.34 & 1.39 & 0.85 & 1.00 \\
\hline $\mathrm{Gd}$ & 4.72 & 1.05 & 4.11 & 1.01 & 0.41 & 1.73 & 3.75 & 0.98 & 0.04 & 0.42 & 0.33 & 2.10 & 0.27 & 1.01 & 6.20 & 6.23 & 4.58 & 5.32 \\
\hline $\mathrm{Tb}$ & 0.48 & 0.03 & 0.41 & 0.27 & 0.04 & 0.35 & 1.00 & 0.14 & 0.01 & 0.05 & 0.08 & 0.50 & 0.06 & 0.19 & 1.01 & 1.04 & 0.82 & 0.89 \\
\hline Dy & 2.55 & 0.15 & 2.59 & 1.53 & 0.50 & 2.07 & 5.75 & 0.68 & 0.05 & 0.35 & 0.52 & 3.30 & 0.40 & 1.03 & 5.47 & 5.50 & 4.55 & 4.92 \\
\hline Ho & 0.52 & 0.12 & 0.60 & 0.31 & 0.08 & 0.44 & 1.01 & 0.14 & 0.01 & 0.11 & 0.09 & 0.74 & 0.12 & 0.25 & 1.00 & 1.03 & 0.97 & 0.89 \\
\hline Er & 1.67 & 0.28 & 1.72 & 0.78 & 0.22 & 1.20 & 2.77 & 0.54 & 0.05 & 0.18 & 0.34 & 2.20 & 0.05 & 0.67 & 2.94 & 3.06 & 3.04 & 2.60 \\
\hline $\mathrm{Tm}$ & 0.32 & $<0.0$ & 0.15 & 0.15 & 0.04 & 0.16 & 0.33 & 0.06 & 0.00 & 0.02 & 0.07 & 0.33 & $<0.0$ & 0.03 & 0.47 & 0.47 & 0.48 & 0.41 \\
\hline $\mathrm{Yb}$ & 1.04 & 0.06 & 0.71 & 0.66 & 0.23 & 0.96 & 1.93 & 0.34 & 0.05 & 0.16 & 0.29 & 2.05 & 0.32 & 0.56 & 3.14 & 3.33 & 3.34 & 3.16 \\
\hline $\mathrm{Lu}$ & 0.08 & 0.03 & 0.17 & 0.08 & 0.03 & 0.14 & 0.26 & 0.05 & 0.01 & 0.03 & 0.04 & 0.30 & 0.04 & 0.11 & 0.43 & 0.45 & 0.49 & 0.40 \\
\hline$\Sigma \mathrm{REE}$ & 93.73 & 14.86 & 131.33 & 20.75 & 7.42 & 46.97 & 64.73 & 32.17 & 2.24 & 19.25 & 16.40 & 46.52 & 18.26 & 88.23 & 220.02 & 238.66 & 198.49 & 230.28 \\
\hline LREE & 82.34 & 13.15 & 120.88 & 15.97 & 5.87 & 39.93 & 47.93 & 29.22 & 2.01 & 17.93 & 14.65 & 35.00 & 17.01 & 84.38 & 199.37 & 217.54 & 180.23 & 211.70 \\
\hline HREE & 11.39 & 1.72 & 10.45 & 4.78 & 1.54 & 7.04 & 16.80 & 2.95 & 0.22 & 1.32 & 1.75 & 11.52 & 1.25 & 3.85 & 20.65 & 21.12 & 18.26 & 18.58 \\
\hline$\delta \mathrm{Ce}$ & 0.85 & 0.76 & 0.96 & 1.02 & 0.48 & 1.05 & 1.08 & 0.86 & 0.81 & 0.63 & 0.71 & 0.91 & 0.38 & 0.81 & 0.90 & 0.94 & 0.90 & 0.87 \\
\hline$\delta \mathrm{Eu}$ & 1.02 & 0.43 & 0.78 & 1.06 & 1.88 & 0.68 & 0.91 & 1.71 & 0.14 & 2.63 & 0.78 & 1.07 & 1.39 & 0.96 & 0.61 & 0.60 & 0.55 & 0.51 \\
\hline
\end{tabular}




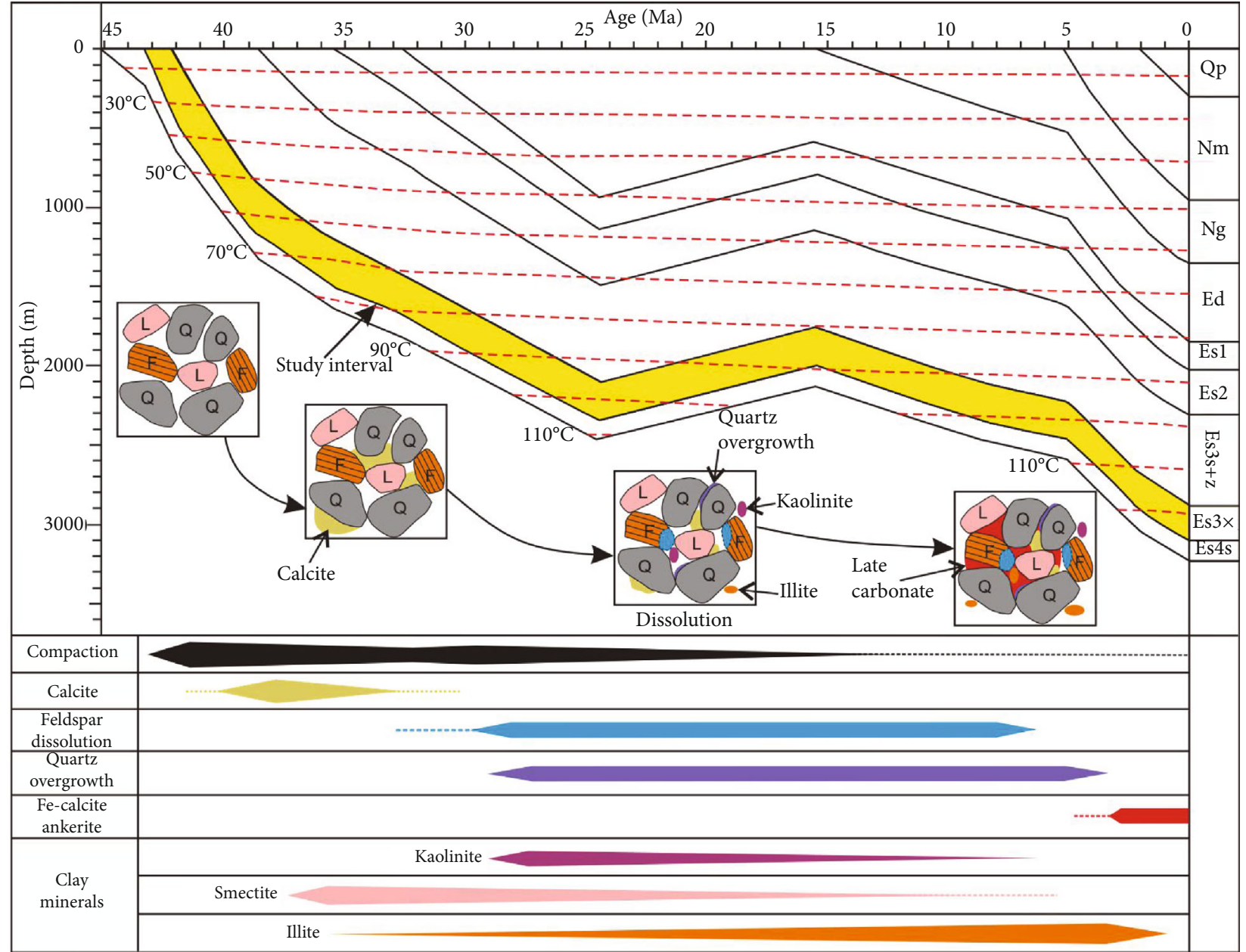

FIGURE 12: Burial and diagenetic history of the Es3x Formation sandstone reservoirs, modified from [27, 29].

the textural relationship through petrological observations. First, rock particles normally displayed point contacts and a floating structure, indicating weak compaction when early-stage calcite filled the intergranular pores (Figures 4(a), 4(g), and 4(h)). However, the content of early-stage calcite cement was relatively low in thin sections. Second, calcite and feldspar dissolutions were accompanied with authigenic mineral precipitations within reservoirs, which is supported by quartz overgrowths and kaolinite that are normally observed near dissolved feldspar and that occupy the intergranular pores (Figures 4(b), 4(d), and 4(f )). The compaction further destroyed the pore spaces of reservoirs and was controlled by different burial history owing to the particles being dominated by line to concavo-convex contacts. Moreover, K-feldspar reacted with kaolinite and smectite was converted into illite in reservoirs, thereby promoting the formation of mixed-layer illite/smectite or illite during progressive burial $[12,38]$. Thus, the illite content gradually increased whereas the kaolinite content began to decrease at approximately $2600 \mathrm{~m}$. The mixed-layer ratios (S\% in I/S) of illite/smectite decreased as the depth increased (Figure 7). Finally, late-stage Fe-calcite and ankerite formed as dominant pore-filling cements, occupying the intergranu- lar and intragranular pores and growing around the euhedral quartz overgrowth (Figures 4(c), 4(d), and 4(i)).

In summary, beach-bar sandstone reservoirs in the Boxing Sag mainly experienced compaction and calcite cementation in the early stage; calcite and feldspar dissolution were accompanied with the precipitation of quartz and kaolinite as well as clay minerals conversion; and Fe-calcite and ankerite cementation occurred in the late stage (Figure 12).

\subsection{Origin of Cementation}

5.2.1. Quartz Cementation. The origin of silica of quartz cements in the sandstone reservoirs can be divided into internal and external sources $[25,39]$. Internal sources normally comprise feldspar and rock fragment dissolution, clay mineral reaction, pressure solution of quartz particles, and biogenic silica [26, 40-42]. External sources generally include the transport of deep fluids $[43,44]$.

Quartz cements are unlikely to stem from biogenetic silica because the sandstones being study are sediments deposited in a lacustrine environment rather than in a marine environment. Petrography analysis also shows no evidence of the existence of biological silicon materials. Additionally, 


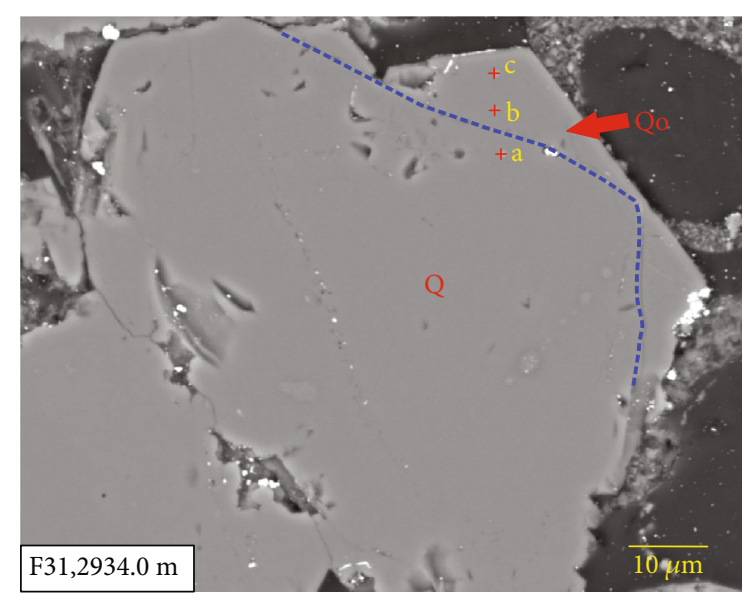

(a)

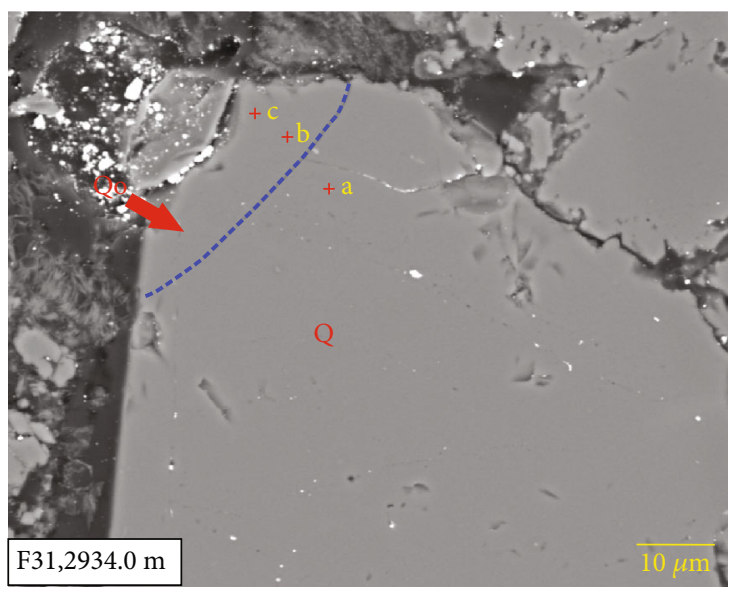

(c)

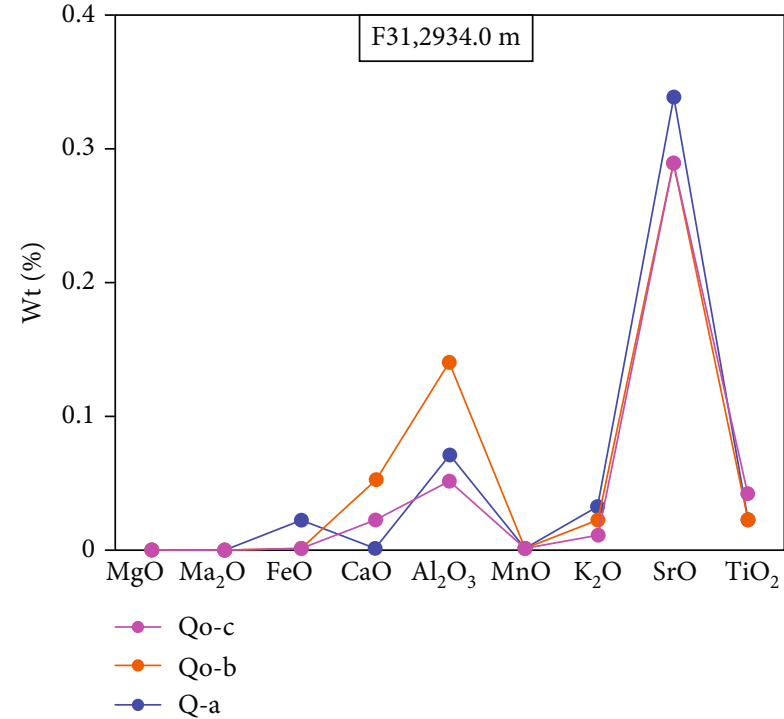

(b)

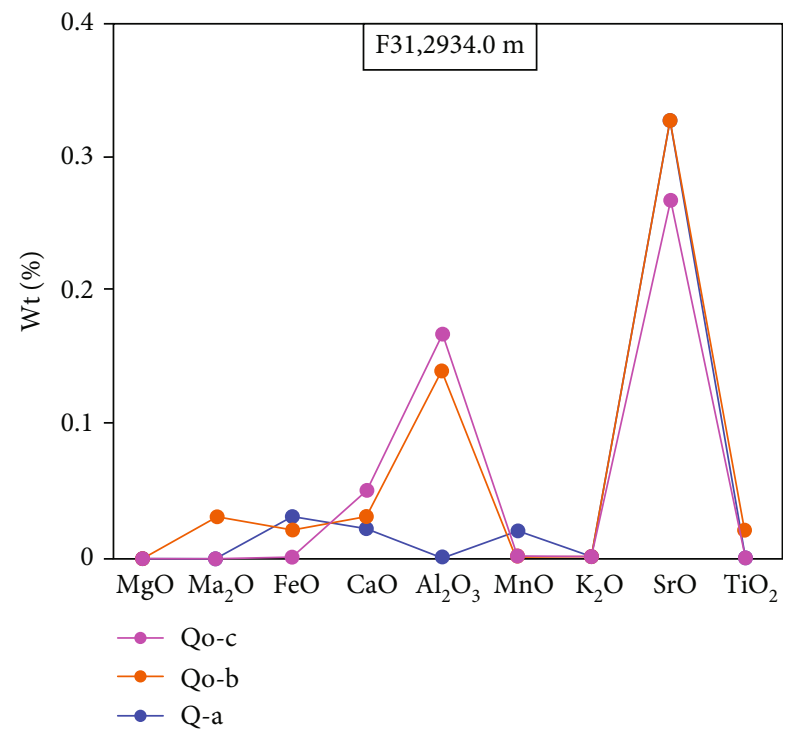

(d)

FIgUre 13: Continued. 

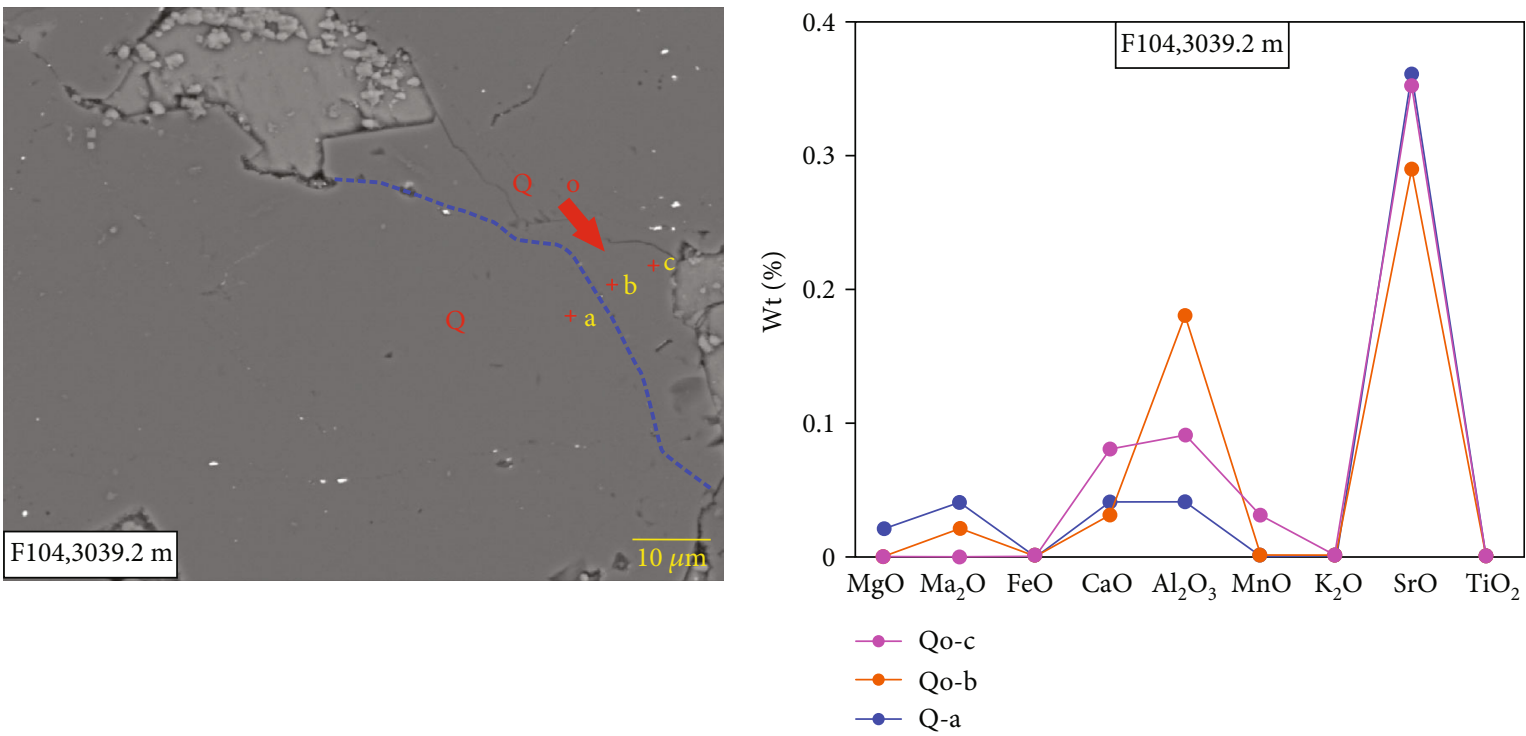

(e)

(f)
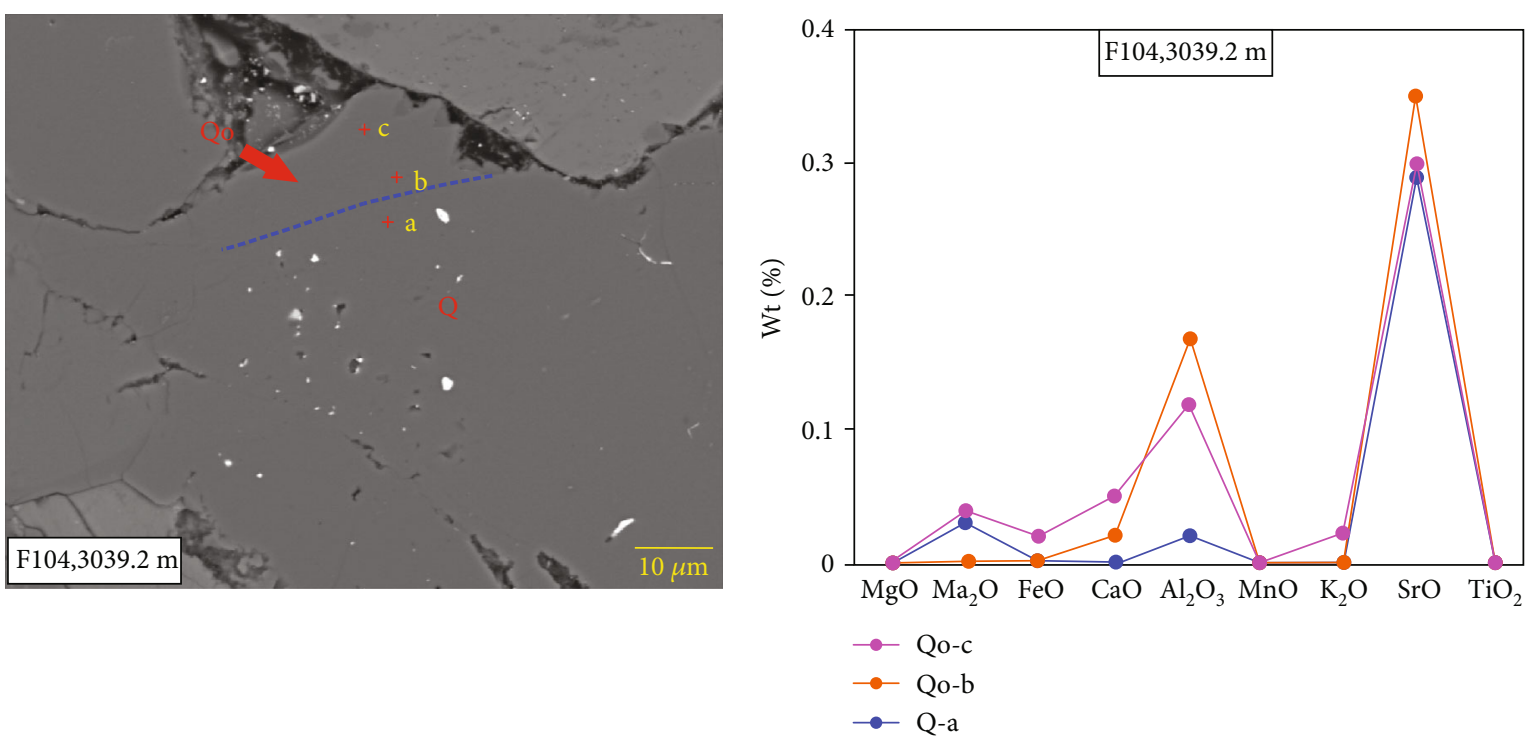

(g)

(h)

FIgURE 13: Continued. 


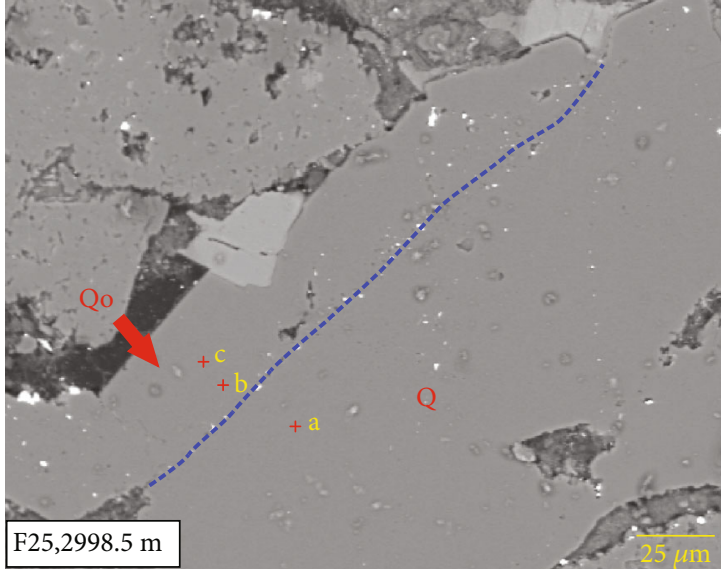

(i)

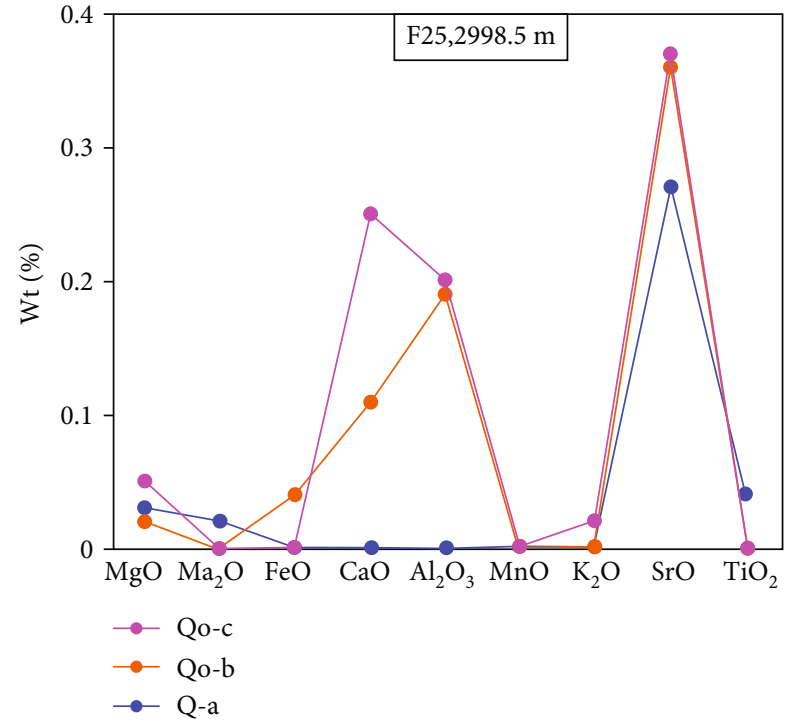

(j)

FIGURE 13: EPMA analysis of detrital quartz and quartz overgrowth (Qo) in the Es3x interval. (a, c, e, g, i) BSE images showing the EPMA analysis position. (b, $d, f, h, j)$ Elemental composition characteristics in detrital quartz and Qo.

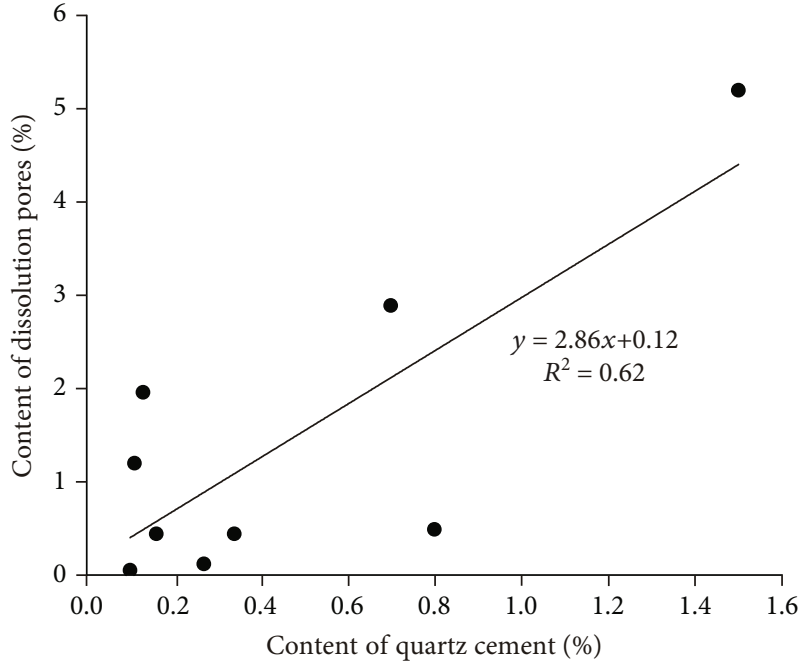

Figure 14: Relationship between the content of feldspar dissolution pores and quartz cement.

Wang et al. [21, 22] reported that the silica sources for quartz overgrowths were mainly influenced by hydrothermal fluids in the Permian Upper Shihezi Formation sandstones at the Qingcheng Rise, which is approximately only $15 \mathrm{~km}$ away from the wells in the study area (Figure 1), because the Th $\left({ }^{\circ} \mathrm{C}\right)$ of aqueous inclusions was higher than its maximum burial temperature, $\delta \mathrm{Eu}$ anomaly, and the enrichment of several trace elements in quartz overgrowths. However, quartz overgrowths of samples herein do not appear abnormally high Th value of aqueous inclusions and the presence of different of major elements (Figures 11 and 13). The pressure dissolution of detrital quartz grains possibly provides little internal silica source owing to the particles that are dominated by a point-to-line contact in the Es3x sandstone. Thus, the silica sources of authigenic quartz primarily originate from the clay mineral reactions and feldspar and rock fragment dissolutions.

The volcanic rock fragments are distributed in the Shahejie Formation beach-bar sandstones and easily transformed into smectite within reservoirs during the early diagenesis ([25]; Figure 7). During progressive diagenesis, the conversion reaction of smectite to illite mainly occurs at approximately $70^{\circ} \mathrm{C}-100^{\circ} \mathrm{C}$, which probably provides a certain amount of silica for the precipitation of quartz [38, 41]. Petrographic observations show the precipitation of authigenic microquartz grains growing together with the clay minerals and the content of illite increasing as the burial depth increases. These results support the generation of quartz cement was associated with the conversion of smectite.

Furthermore, petrographic observations show that the generation of authigenic quartz overgrowths was normally accompanied with feldspar dissolution, which could be an origin for quartz cementation. In addition to the ion concentration, the $\mathrm{pH}$, temperature and pressure, chemical composition, and structure of plagioclase are key factors determining the dissolution or precipitation process. This is based on thermodynamic calculations that show the solubility of plagioclase increases as the calcium content increases [45]. Therefore, the dissolution of early calcite and feldspars probably leads to the enrichment of $\mathrm{Ca}^{2+}$, followed by $\mathrm{Na}^{+}$and $\mathrm{K}^{+}$in the pore water. The $\mathrm{Al}^{3+}$ widely existed in the reaction process of aluminosilicate minerals [12]. The numerical simulations indicated that the silica formed by feldspar dissolution is locally precipitated in the deep burial process, which can be further proved by a 


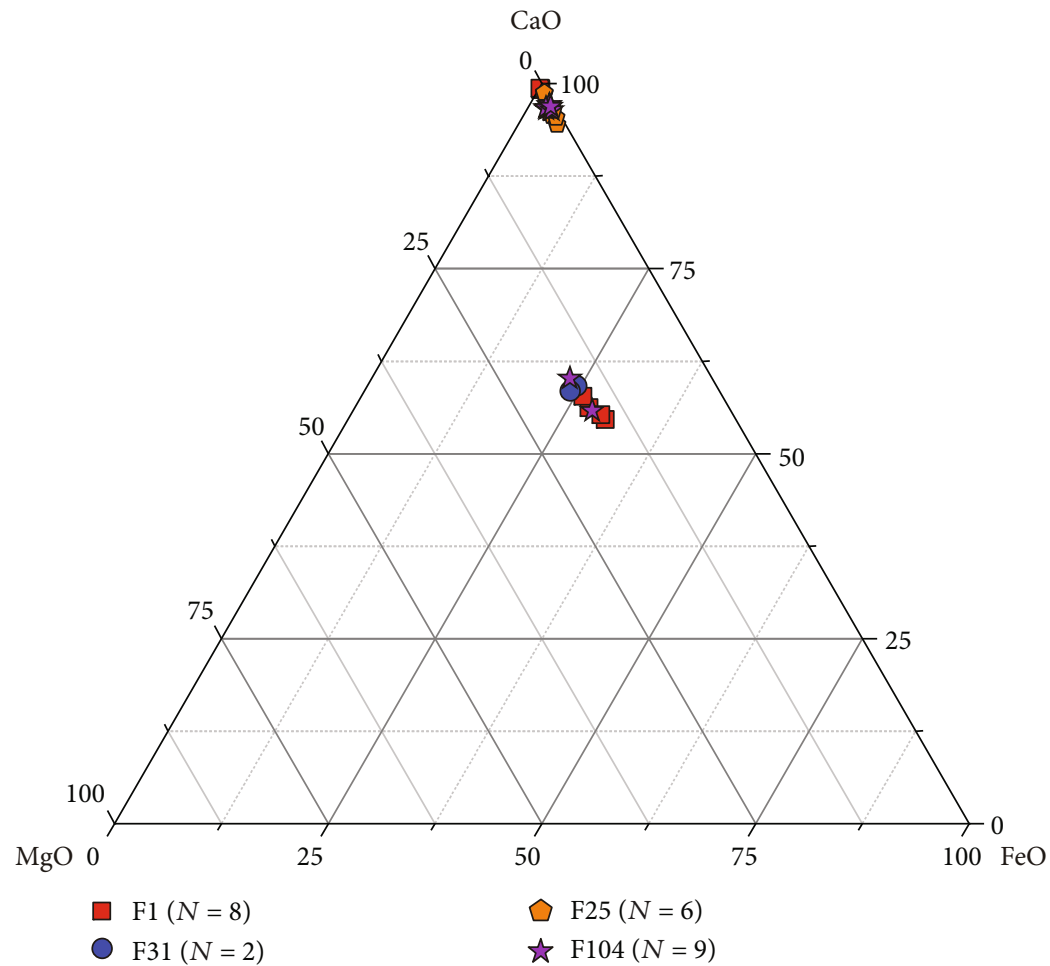

FIGURE 15: Ternary diagrams showing normalized compositions of carbonate cement from EPMA analysis in wt\%.

positive relationship between the content of feldspar dissolution pores and quartz cement (Figure 14; [33]).

5.2.2. Carbonate Cementation. Carbonate minerals as cements are universal and normally occupy the pore space of sandstone samples. Petrographic and EPMA analyses reveal the presence of calcite, Fe-calcite, and ankerite. The signals of major elements and the REE content of carbonate cements probably provide the clues about the origin of late Fe-calcite and ankerite. The external sources include the precipitation of carbonate from meteoric water, adjacent mudstones, and deep fluids $[8,31]$. Internal sources include the dissolution of detrital carbonate grains, early carbonate, and unstable compositions as well as the conversion of clay minerals [46].

The late-stage Fe-calcite and ankerite minerals not only contain higher amounts of $\mathrm{FeO}$ and $\mathrm{MgO}$ (Figure 15) but also contain slightly higher amounts of $\mathrm{SrO}, \mathrm{Na}_{2} \mathrm{O}, \mathrm{Al}_{2} \mathrm{O}_{3}$, and $\mathrm{K}_{2} \mathrm{O}$ compared with calcite (Figure 16). The calcite with high $\mathrm{MnO}$ content formed in the early stage is mainly influenced by mudstone [17, 31]. Mn-oxide reduction by organic matter at low temperatures could result in the enrichment of $\mathrm{Mn}^{2+}$ in calcite that showed bright yellow luminescence [47]. The Th $\left({ }^{\circ} \mathrm{C}\right)$ of late-stage carbonate cements exceeds $115^{\circ} \mathrm{C}$, suggesting that the organic matter has already discharged a large amount of organic acids and $\mathrm{CO}_{2}$, which contributed to the dissolution of feldspars and early calcites as well as the reprecipitation of late carbonate. Additionally, the persistent conversion of clay minerals also supplies abundant cations in the pore water. Thus, the ions $\left(\mathrm{Ca}^{2+}, \mathrm{Fe}^{2+}, \mathrm{Mg}^{2+}\right.$,
$\mathrm{Na}^{+}, \mathrm{K}^{+}$, and $\mathrm{Al}^{3+}$ ) for the formation of late Fe-calcites and ankerites were probably derived from the dissolution of preexisting minerals and the conversion of clay minerals locally. Besides, previous research indicated that the micritic carbonate within mudstones in the Dongying Depression exhibited a high content of $\mathrm{Sr}^{2+}$ [14], which gradually entered into pore water, resulting in a high $\mathrm{SrO}$ content in late-stage carbonate. The presence of barite was normally associated with hydrothermal fluid [21,22]. The barite mineral has markedly low solubility, whereas barium is common within the organic matter $[48,49]$. The dissolution of gypsum within mudstone provided sulfate into pore water to promote the precipitation of barite [50].

The REE signature reflects whether the external meteoric water and deep fluids are involved in the formation of carbonate cements. The mudstones in the study area were normally enriched in LREE content and demonstrated HREE depletion as well as a slight negative anomaly in the $\delta \mathrm{Eu}$ value (Figure 17(a)). The late-stage carbonate cements typically demonstrated similar REE patterns because the recrystallization of carbonate can cause a variety in total REE content ( $\Sigma \mathrm{REE}$ ) rather than variable REE patterns (Figures 17 (b) and $17(\mathrm{c})$ ). The index of the $\delta \mathrm{Ce}$ value can reveal the impact of meteoric water $[51,52]$. The $\delta$ Ce values of late carbonate cements have an average of 0.81 , which is close to the $\delta$ Ce values of mudstones, and do not show obvious anomaly. Moreover, the $\delta$ Eu anomalies are utilized to assess the impact of hydrothermal fluids as the $\mathrm{Eu}$ is enriched in highly reducing hydrothermal fluids [53]. The late-stage carbonate cements demonstrate significantly 


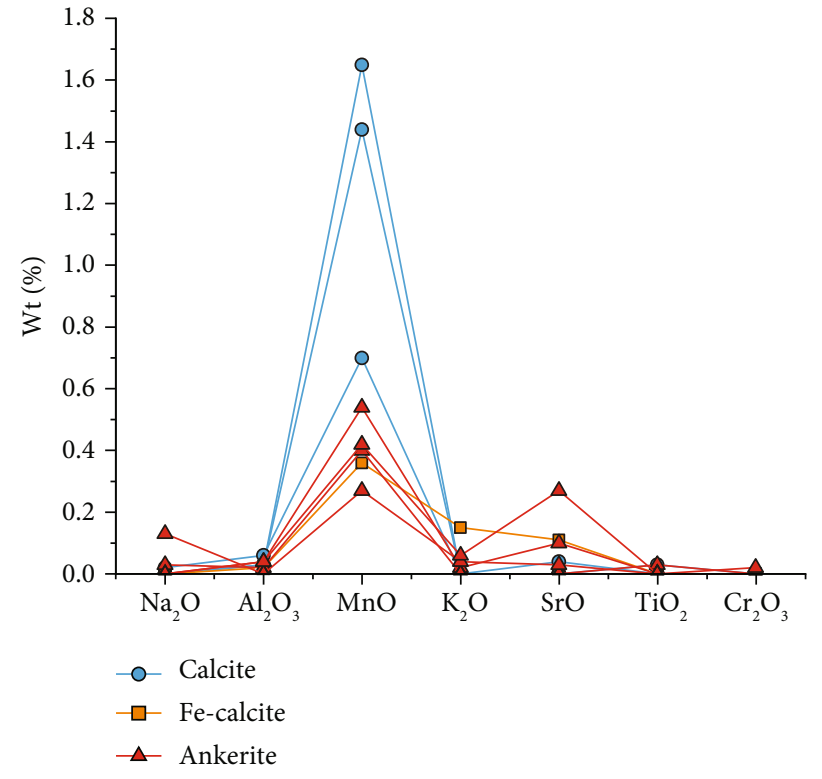

(a)

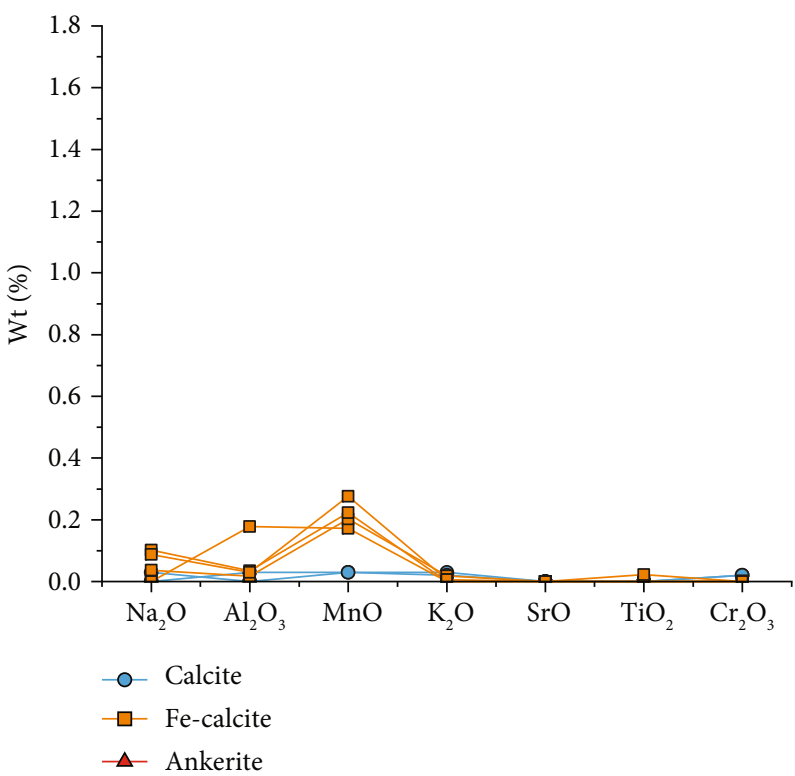

(c)

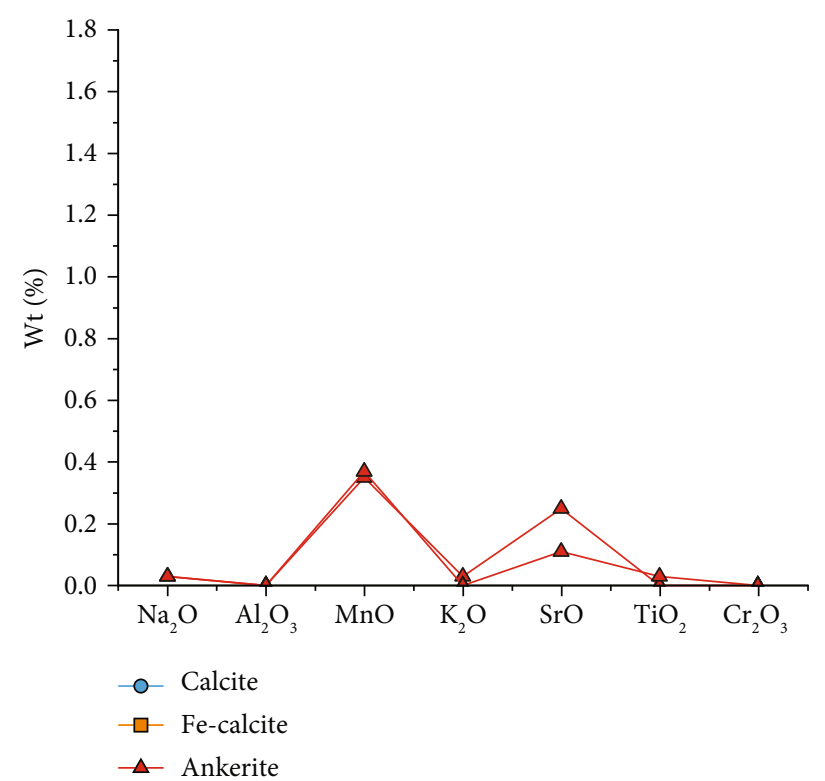

(b)

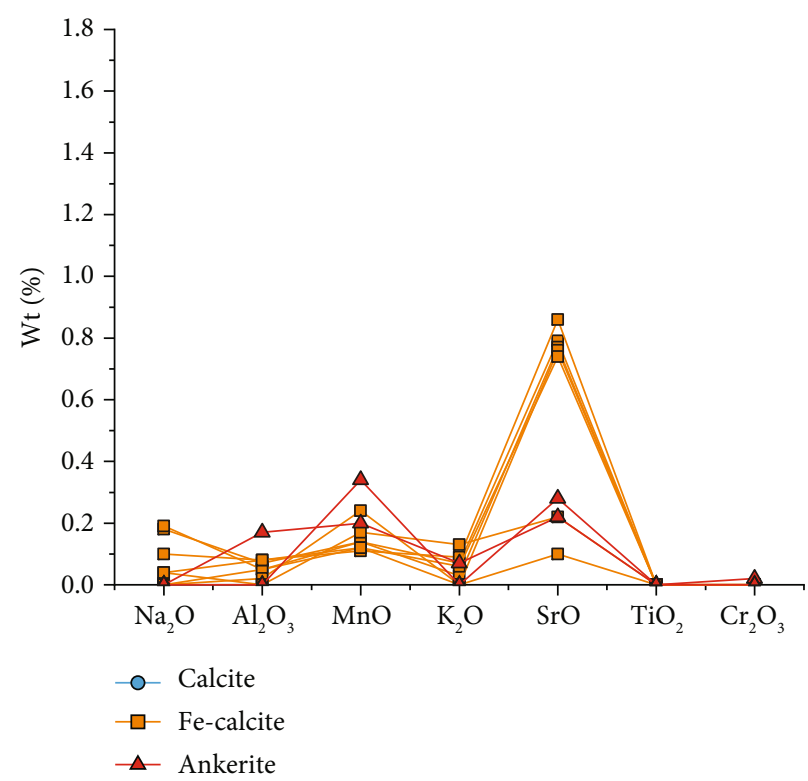

(d)

Figure 16: Major elements of carbonate cement from EPMA analysis. (a) F1 well; (b) F31 well; (c) F25 well; and (d) F104 well.

fluctuations in the $\delta$ Eu values, with an average of 1.10 , which is larger than the $\delta \mathrm{Eu}$ values of mudstones and displays a slightly positive $\mathrm{Eu}$ anomaly, which probably reveals that hydrothermal fluids are involved in the precipitation of late carbonate [54]. However, the Th $\left({ }^{\circ} \mathrm{C}\right)$ of late-stage carbonate ranges between $118^{\circ} \mathrm{C}$ and $126^{\circ} \mathrm{C}$, which indicates a normal burial condition and is inconsistent with the hydrothermal fluid source (Figure 12). The feldspars dissolution, particularly plagioclases with a high calcium content, which provides divalent $\mathrm{Eu}$ into pore water owing to the divalent $\mathrm{Eu}$, tends to enter the crystal lattice of plagioclase and results in increased $\delta$ Eu values within late carbonate in the reducing environment $[19,55]$. Therefore, the formation of late car- bonate cements is mainly influenced by the carbonate signature within mudstone owing to the similar REE patterns. Unstable mineral dissolution and clay mineral conversion result in ions being supplied to pore water, changing the major and trace elements within late-stage carbonate.

5.3. Diagenetic Fluid Transformation and Evolution. The petrological features demonstrated that beach-bar sandstone reservoirs experienced early-stage calcite cementation, calcite and feldspar dissolution with the precipitation of quartz and kaolinite, and late-stage cementation for Fe-calcite and ankerite. The Th $\left({ }^{\circ} \mathrm{C}\right)$ of fluid inclusion provides more detailed information about the evolution of diagenetic fluids. 


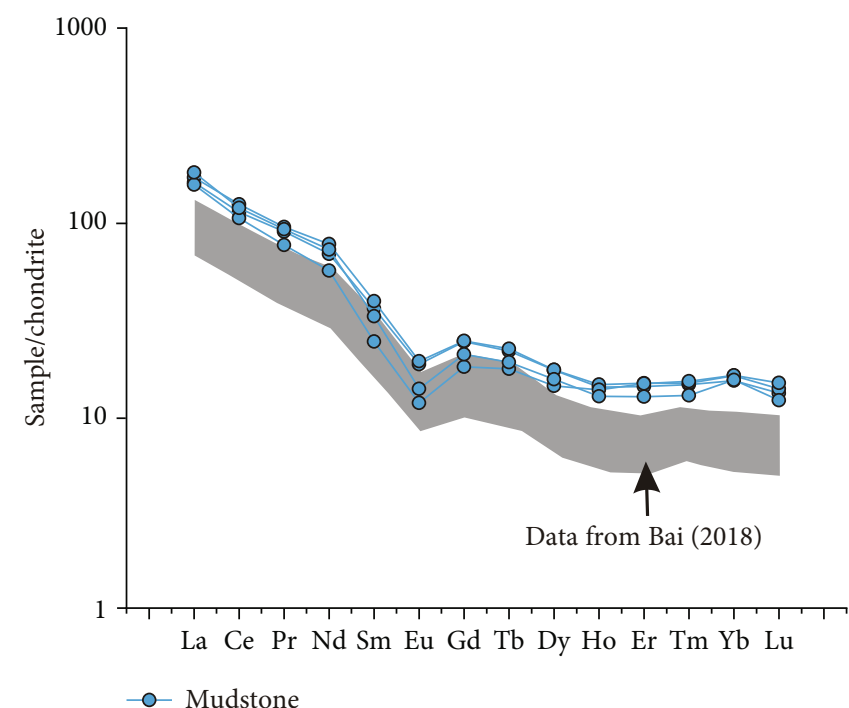

(a)

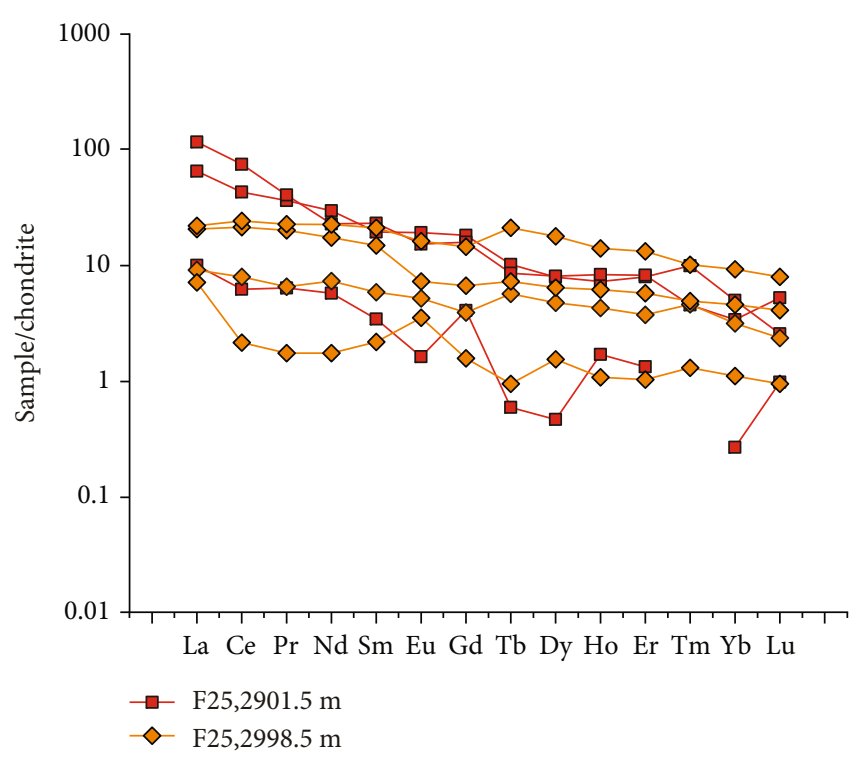

(b)

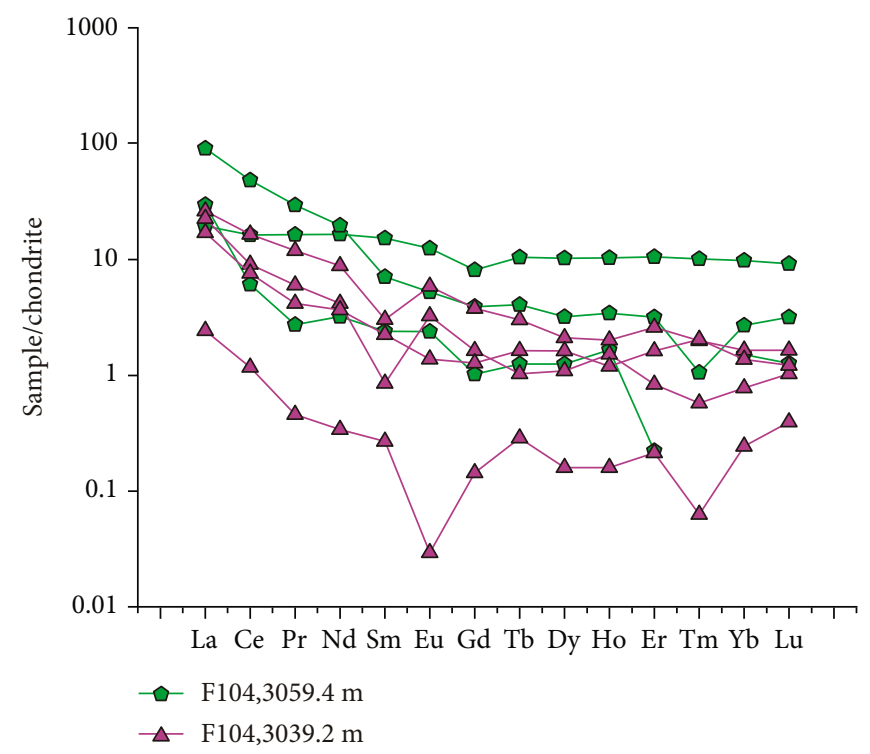

(c)

FIGURE 17: Spider diagram of the pattern of rare earth element (REE). Chondrite-normalized REE patterns in (a) mudstones and data from Bai et al. [14] and in carbonate cements within Es3x interval from (b) F25 and (c) F104 wells, respectively.

The $\mathrm{Th}\left({ }^{\circ} \mathrm{C}\right)$ of quartz overgrowths and late carbonate cements in the Es3x sandstone range from $99^{\circ} \mathrm{C}$ to $129^{\circ} \mathrm{C}$ and from $118^{\circ} \mathrm{C}$ to $126^{\circ} \mathrm{C}$, respectively, and the $\mathrm{Th}\left({ }^{\circ} \mathrm{C}\right)$ of quartz overgrowths of well G351 in the Es4s sandstone ranges from $106^{\circ} \mathrm{C}$ to $121^{\circ} \mathrm{C}$ (Figure 11$)$. These Th $\left({ }^{\circ} \mathrm{C}\right.$ ) values are similar to the previous results in quartz overgrowths $\left(90^{\circ} \mathrm{C}\right.$ to $\left.120^{\circ} \mathrm{C}\right)$ and late-stage carbonate cementation $\left(115^{\circ} \mathrm{C}\right.$ to $135^{\circ} \mathrm{C}$; [27]). They indicate that the impact of acidic fluid probably begins at $\sim 90^{\circ} \mathrm{C}$ and continues until $\sim 115^{\circ} \mathrm{C}$.

The precipitation of early-stage calcite among intergranular pores is probably affected by the ions resulting from mudstone compaction in an alkaline environment. The biodegradation of oils requires the participation of aerobic bac- teria and oxidants carried by meteoric water and can produce organic acids to dissolve minerals within reservoir [56]. However, beach-bar sandstone reservoir is continuously buried based on the burial history, rather than tectonic uplift (Figure 12). Additionally, fluid overpressure is developed (Figure 1(c)), and the by-products from feldspar dissolution can always be observed nearby and generally obeys the principle of mass balance in a closed system (Figure 14; $[6,33])$, which indicate that meteoric water may have little effect on the dissolution of minerals in the reservoirs. Thus, the thermal degradation of kerogen within mudstone discharges an acidic fluid into the reservoirs to dissolve the preexisting calcite and feldspar, which provide major silica sources for the growth of authigenic quartz. The formation 
of late-stage Fe-calcite and ankerite minerals are mainly influenced by mudstone fluids formed in alkaline conditions, based on the Th $\left({ }^{\circ} \mathrm{C}\right)$ of fluid inclusions and major and trace elements signature. Moreover, the $\mathrm{C}-\mathrm{O}$ isotopes of carbonate cements represent the thermal evolution of organic matter and provide additional information about diagenetic fluids [57]. $\delta^{13} \mathrm{C}$ and $\delta^{18} \mathrm{O}$ of micritic carbonate within mudstone possibly reflect the carbonate characteristics during the sedimentary period. Their averages are $3.5 \%$ and $-9.5 \%$, respectively [14]. The negative shift of $\delta^{18} \mathrm{O}$ within late carbonate cement indicates the higher temperature of precipitation because $\delta^{18} \mathrm{O}$ is sensitive to the diagenetic temperature [58]. The $\delta^{13} \mathrm{C}$ value is deemed an effective index for organic-inorganic interaction in the diagenetic process [59] and is associated with preexisting carbonate dissolution, bacterial sulfate reduction, microbial degradation of organic matter, and thermal decarboxylation of hydrocarbons [60, 61]. The similar distribution of $\delta^{13} \mathrm{C}$ values in micritic carbonate and late-stage carbonate cements within the Es3x sandstone indicates that the fluid for late-stage carbonate cements mainly originate from micritic carbonate and preexisting calcite. Conversely, the Es4s sandstone experiences a longer burial process and the decarboxylation of organic matter, which contributes to carbonate cements having negative $\delta^{13} \mathrm{C}$ values that are obviously lower than that of the Es3x sandstone and micritic carbonate (Figure 18). Thus, beach-bar sandstone reservoirs in the Boxing Sag generally evolved from being alkaline to acidic to alkaline. The acidic environment probably lasted for approximately $27 \mathrm{Ma}$ (from $\sim 30 \mathrm{Ma}$ to $\sim 3 \mathrm{Ma}$ ) and $28 \mathrm{Ma}$ (from $\sim 32 \mathrm{Ma}$ to $\sim 4 \mathrm{Ma}$ ) in the Es3x and Es4s sandstones, respectively (Figure 12).

5.4. Impacts on the Reservoir Quality. Sandstones in the research area are characterized by the general proportion of low-porosity and high proportion of low-permeability reservoirs (Figure 8 ), which probably implies that the sandstone reservoirs exhibit complex pore structures and heterogeneity. HPMI results also indicate that beach-bar sandstone samples are dominated by micropores, which increase the complexity of pore throat structures and decrease the permeability of sandstone reservoirs. The original depositional environments and later diagenesis determine the pore structure of sandstones, which significantly helps in maintaining and enhancing oil recovery $[1,62,63]$. The depositional environments include the framework grain compositions, size, sorting, and shape and affect the initial pore space among grains. However, the sandstone samples exhibit similar grain compositions, grain sizes, and sorting coefficient (Table 1), which probably indicate that these sandstones exhibit a slightly different initial porosity. Therefore, diagenetic modifications involving compaction, dissolution, and cementation during the burial process further reshape the pore structure and mainly control the sandstone reservoir quality. The petrographic analysis of samples indicates that compaction has the most negative influence on the reservoir quality (Figure 19). Meanwhile, cementation, particularly the content of carbonate cement, also significantly helps in reducing the reservoir quality of sandstones in certain sam-

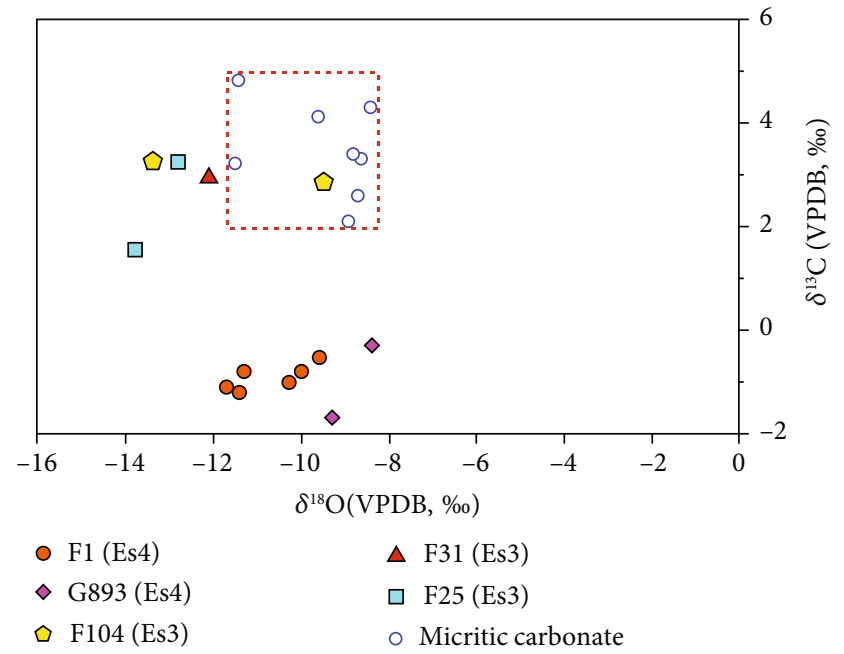

FIgURE 18: Carbon and oxygen isotopic compositions of carbonate cements and micritic carbonate (red box) within mudstone from Bai et al. [14].

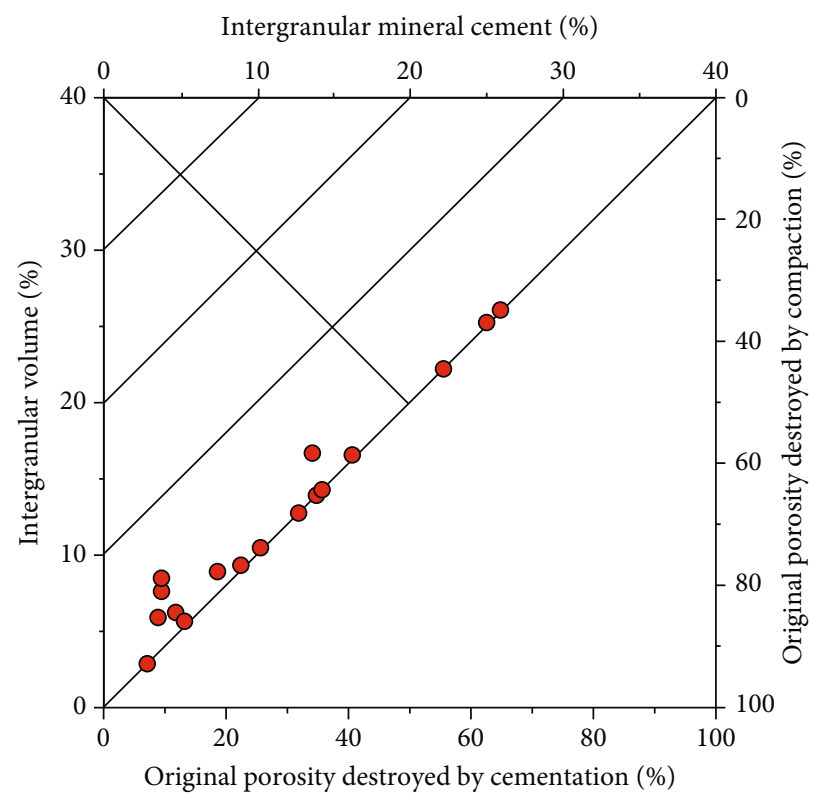

FIGURE 19: Diagram showing the compaction porosity loss versus cementation porosity loss in the sandstone reservoirs [65].

ples owing to a negative correlation between the plane porosity and carbonate cements (Figure 20(a)). Previous researches have also proved that the distance to the sandstone-mudstone contact normally controls the precipitation of early-stage calcite. However, the carbonate in this research mostly consists of late-stage Fe-calcite and ankerite, which is a product of the water-rock reaction and records the signature of diagenetic fluids. The content of carbonate cementation has a negative relationship with the distance to sandstone-mudstone contact, as well as a slightly negative relationship with porosity and permeability (Figures 20(b) and 21), implying mass balance in a closed system within sandstone reservoirs. 


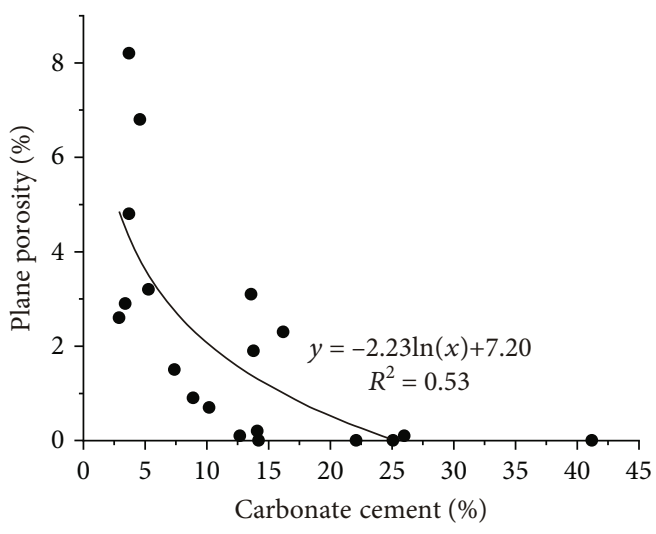

(a)

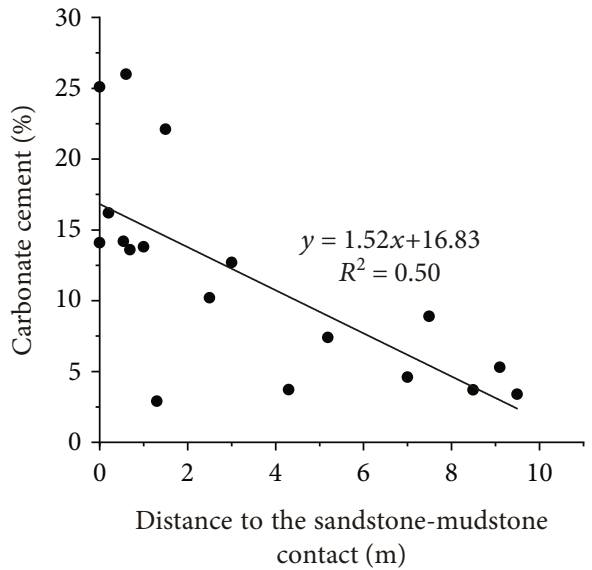

(b)

FIGURE 20: Relationship between the content of carbonate cement, plane porosity of thin section, and the distance from sandstonemudstone contact.

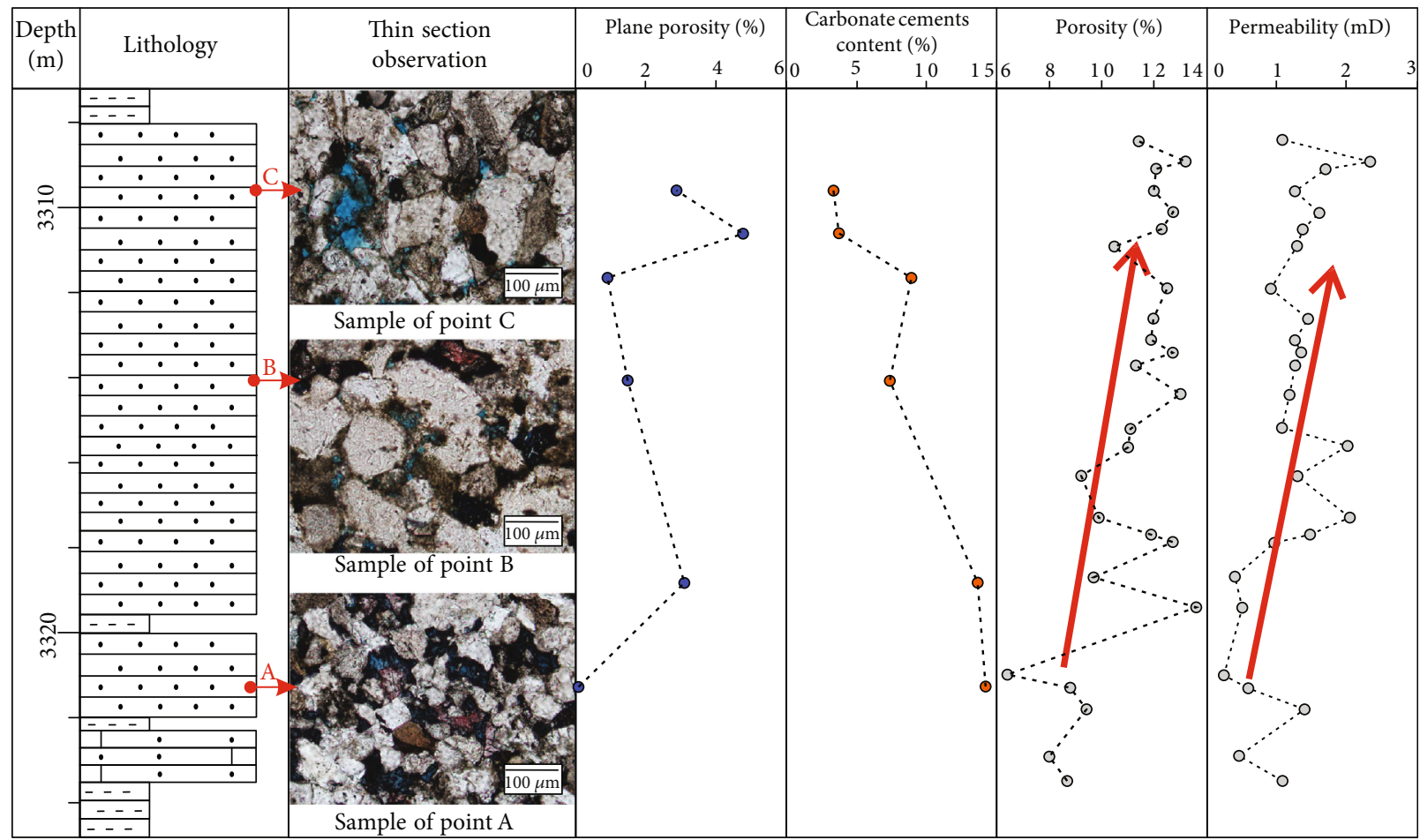

FIGURE 21: Vertical distribution of plane porosity and carbonate content of thin sections, porosity, and permeability in the F1 well in the Boxing Sag. Point A: all intergranular pores are destroyed by strong carbonate cementation; point B: a small amount of intergranular pores and carbonate cements; point C: intergranular pores are relatively common.

\section{Conclusions}

(1) The Eocene beach-bar sandstones are dominated by micropores in the Boxing Sag and mainly underwent continuous compaction as well as calcite cementation in the early stage; then, calcite and feldspar dissolution were accompanied by the precipitation of quartz and kaolinite as well as the conversion of clay minerals. Intergranular and intragranular pores were partly destroyed by compaction and cemented by $\mathrm{Fe}$ - calcite and ankerite in the late stage. Thus, beach-bar sandstone reservoirs generally experienced alkalineacid-alkaline conditions

(2) The generation of quartz cementation is mainly related to the dissolution of plagioclase with a high calcium content and early calcite providing the silica and $\mathrm{Ca}^{2+}$ source in a closed system. The conversion of clay minerals during the burial process probably contributes a small amount of silica into pore water 
(3) Early-stage calcite with a relatively higher proportion of $\mathrm{MnO}$ shows yellow luminescence and dissolution signs. Late-stage Fe-calcite and ankerite cements have higher Th than quartz overgrowth and mainly concentrate in $\mathrm{Fe}^{2+}$ and $\mathrm{Mg}^{2+}$ as well as a small number of other cations $\left(\mathrm{Na}^{+}, \mathrm{K}^{+}\right.$, and $\left.\mathrm{Sr}^{2+}\right)$. The diagenetic fluids of carbonate cementation are mainly controlled by the adjacent mudstone owing to the similarity of REE pattern. The dissolution of minerals and the conversion of clay minerals supply extra cations for the reprecipitation of late carbonate locally and induce the fluctuation of $\delta \mathrm{Eu}$ values

(4) The compaction significantly reduces pore spaces of beach-bar sandstone reservoirs in the Boxing Sag. Additionally, carbonate cements probably further increase the complexity of pore structure and obey the principle of mass balance.

\section{Data Availability}

The fluid inclusion, C-O isotope, EPMA, and REE data used to support the findings of this study are included within the article. The porosity and permeability and XRD data used to support the findings of this study were supplied by the Shengli Oilfield Company, SINOPEC, under license and so cannot be made freely available. Requests for access to these data should be made to Zhenhuan Shen (shenzh9311@163.com).

\section{Conflicts of Interest}

The authors declare that they have no conflicts of interest.

\section{Acknowledgments}

We thank the Research Institute of Exploration and Development, Shengli Oilfield Company, Sinopec, for sample and data access; Ru Sun, Yi Yuan, and Guoping Chen for sample collection assistance and petrological observation; and Beijing Research Institute of Uranium Geology for experiment support. This study is supported by Important Science \& Technology Specific Projects of Sinopec (ZDP17008).

\section{References}

[1] J. Lai, G. Wang, Z. Wang et al., "A review on pore structure characterization in tight sandstones," Earth-Science Reviews, vol. 177, pp. 436-457, 2018.

[2] S. Morad, K. al-Ramadan, J. M. Ketzer, and L. F. de Ros, "The impact of diagenesis on the heterogeneity of sandstone reservoirs: a review of the role of depositional facies and sequence stratigraphy," AAPG Bulletin, vol. 94, no. 8, pp. 1267-1309, 2010.

[3] K. Xi, Y. Cao, J. Jahren et al., "Diagenesis and reservoir quality of the Lower Cretaceous Quantou Formation tight sandstones in the southern Songliao Basin, China," Sedimentary Geology, vol. 330, pp. 90-107, 2015.

[4] S. Zhu, X. Zhu, Y. Jia, H. Cui, and W. Wang, "Diagenetic alteration, porethroat network, and reservoir quality of tight gas sandstone reservoirs: a case study of the upper Paleozoic sequence in the northern Tianhuan depression in the Ordos Basin, China," AAPG Bulletin, vol. 104, no. 11, pp. 22972324, 2020.

[5] K. Bjørlykke, "Relationships between depositional environments, burial history and rock properties. Some principal aspects of diagenetic process in sedimentary basins," Sedimentary Geology, vol. 301, pp. 1-14, 2014.

[6] G. Yuan, Y. Cao, J. Gluyas et al., "Feldspar dissolution, authigenic clays, and quartz cements in open and closed sandstone geochemical systems during diagenesis: typical examples from two sags in Bohai Bay Basin, East China," AAPG Bulletin, vol. 99, no. 11, pp. 2121-2154, 2015.

[7] B. Ma, Y. Cao, K. A. Eriksson, and Y. Wang, "Carbonate cementation patterns, potential mass transfer, and implications for reservoir heterogeneity in Eocene tight-oil sandstones, Dongying depression, Bohai Bay Basin, China: evidence from petrology, geochemistry, and numerical modeling," AAPG Bulletin, vol. 103, no. 12, pp. 3035-3067, 2019.

[8] W. Wei, X. Zhu, D. Chen, S. Zhu, M. He, and S. Sun, "Pore fluid and diagenetic evolution of carbonate cements in lacustrine carbonate-siliciclastic rocks: a case from the lower cretaceous of the Erennaoer Sag, Erlian Basin, NE China," Journal of Sedimentary Research, vol. 89, no. 5, pp. 459-477, 2019.

[9] H. Mansurbeg, S. Morad, A. Salem et al., "Diagenesis and reservoir quality evolution of palaeocene deep-water, marine sandstones, the Shetland-Faroes Basin, British continental shelf," Marine and Petroleum Geology, vol. 25, no. 6, pp. 514-543, 2008.

[10] B. Ma, K. A. Eriksson, Y. Cao, Y. Jia, Y. Wang, and B. C. Gill, "Fluid flow and related diagenetic processes in a rift basin: evidence from the fourth member of the Eocene Shahejie Formation interval, Dongying depression, Bohai Bay Basin, China," AAPG Bulletin, vol. 100, no. 11, pp. 1633-1662, 2016.

[11] S. Morad, J. M. Ketzer, and L. F. de Ros, "Spatial and temporal distribution of diagenetic alterations in siliciclastic rocks: implications for mass transfer in sedimentary basins," Sedimentology, vol. 47, pp. 95-120, 2000.

[12] K. Bjørlykke and J. Jahren, "Open or closed geochemical systems during diagenesis in sedimentary basins: constraints on mass transfer during diagenesis and the prediction of porosity in sandstone and carbonate reservoirs," AAPG Bulletin, vol. 96, no. 12, pp. 2193-2214, 2012.

[13] T. R. Taylor, M. R. Giles, L. A. Hathon et al., "Sandstone diagenesis and reservoir quality prediction: models, myths, and reality," AAPG Bulletin, vol. 94, no. 8, pp. 1093-1132, 2010.

[14] C. Bai, B. Yu, H. Liu et al., "The genesis and evolution of carbonate minerals in shale oil formations from Dongying depression, Bohai Bay Basin, China," International Journal of Coal Geology, vol. 189, pp. 8-26, 2018.

[15] N. J. F. Blamey, K. Azmy, and U. Brand, "Provenance and burial history of cement in sandstones of the Northbrook Formation (carboniferous), western Newfoundland, Canada: a geochemical investigation," Sedimentary Geology, vol. 299, pp. 30-41, 2014.

[16] J. N. Hooker, J. Cartwright, B. Stephenson, C. R. P. Silver, A. J. Dickson, and Y. T. Hsieh, "Fluid evolution in fracturing black shales, Appalachian Basin," AAPG Bulletin, vol. 101, no. 8, pp. 1203-1238, 2017.

[17] Y. Liu, W. Hu, J. Cao et al., "Fluid-rock interaction and its effects on the Upper Triassic tight sandstones in the Sichuan Basin, China: insights from petrographic and geochemical 
study of carbonate cements," Sedimentary Geology, vol. 383, pp. 121-135, 2019.

[18] B. Ma, Y. Lu, K. A. Eriksson, L. Peng, F. Xing, and X. Li, "Multiple organic-inorganic interactions and influences on heterogeneous carbonate-cementation patterns: example from Silurian deeply buried sandstones, central Tarim Basin, north-western China," Sedimentology., vol. 68, no. 2, pp. 670-696, 2020.

[19] D. Xiong, K. Azmy, and N. J. F. Blamey, "Diagenesis and origin of calcite cement in the Flemish Pass Basin sandstone reservoir (Upper Jurassic): implications for porosity development," Marine and Petroleum Geology, vol. 70, pp. 93-118, 2016.

[20] S. Han, B. Yu, Z. Ruan, C. Bai, Z. Shen, and S. C. Löhr, "Diagenesis and fluid evolution in the third member of the Eocene Shahejie Formation, Bonan Sag, Bohai Bay Basin, China," Marine and Petroleum Geology., vol. 128, article 105003, 2021.

[21] Y. Wang, Y. Fu, Y. Cao et al., "Sources of authigenic quartz in the Permian tight sandstones close to Gaoqing Fault, Dongying Sag, Bohai Bay Basin, China," Marine and Petroleum Geology, vol. 113, article 104109, 2020.

[22] Y. Wang, S. Yang, Y. Zhang, Y. Lu, Y. Wang, and Y. Zhao, "Investigation of pore structure and reservoir quality of Eocene beach-bar sandstones in Dongying Depression, Bohai Bay Basin, East China," Journal of Petroleum Science and Engineering, vol. 189, article 106854, 2020.

[23] K. Azmy and N. J. F. Blamey, "Source of diagenetic fluids from fluid-inclusion gas ratios," Chemical Geology, vol. 347, pp. 246-254, 2013.

[24] K. Xi, Y. Cao, J. Jahren et al., "Quartz cement and its origin in tight sandstone reservoirs of the Cretaceous Quantou formation in the southern Songliao basin, China," Marine and Petroleum Geology, vol. 66, pp. 748-763, 2015.

[25] K. Xi, Y. Cao, K. Liu et al., "Diagenesis of tight sandstone reservoirs in the Upper Triassic Yanchang Formation, southwestern Ordos Basin, China," Marine and Petroleum Geology, vol. 99, pp. 548-562, 2019.

[26] G. Yuan, Y. Cao, J. Gluyas, X. Cao, and W. Zhang, "Petrography, fluid-inclusion, isotope, and trace-element constraints on the origin of quartz cementation and feldspar dissolution and the associated fluid evolution in arkosic sandstones," AAPG Bulletin, vol. 102, no. 5, pp. 761-792, 2018.

[27] Y. Cao, T. Yang, M. Song et al., "Characteristics of lowpermeability clastic reservoirs and genesis of relatively highquality reservoirs in the continental rift lake basin: a case study of Paleogene in the Dongying Sag, Jiyang Depression," Acta Petrolei Sinica, vol. 39, pp. 727-743, 2018.

[28] Z. Jiang, H. Liu, S. Zhang, X. Su, and Z. Jiang, "Sedimentary characteristics of large-scale lacustrine beach-bars and their formation in the Eocene Boxing Sag of Bohai Bay Basin, East China," Sedimentology, vol. 58, no. 5, pp. 1087-1112, 2011.

[29] J. Wang, Y. Cao, J. Xiao, K. Liu, and M. Song, "Factors controlling reservoir properties and hydrocarbon accumulation of the Eocene lacustrine beach-bar sandstones in the Dongying Depression, Bohai Bay Basin, China," Marine and Petroleum Geology, vol. 99, pp. 1-16, 2019.

[30] J. Wang, Y. Cao, K. Liu, J. Liu, and M. Kashif, "Identification of sedimentary-diagenetic facies and reservoir porosity and permeability prediction: an example from the Eocene beach-bar sandstone in the Dongying Depression, China," Marine and Petroleum Geology, vol. 82, pp. 69-84, 2017.
[31] K. Xi, Y. Cao, K. Liu et al., "Geochemical constraints on the origins of calcite cements and their impacts on reservoir heterogeneities: a case study on tight oil sandstones of the Upper Triassic Yanchang Formation, southwestern Ordos Basin, China," AAPG Bulletin, vol. 103, no. 10, pp. 2447-2485, 2019.

[32] F. A. Chuhan, K. Bjorlykke, and C. J. Lowrey, "Closed system burial diagenesis in reservoir sandstones examples from the Garn Formation at Haltenbanken area, Offshore Mid-Norway," Journal of Sedimentary Research, vol. 71, no. 1, pp. 1526, 2001.

[33] G. Yuan, Y. Cao, J. Gluyas, and Z. Jia, "Reactive transport modeling of coupled feldspar dissolution and secondary mineral precipitation and its implication for diagenetic interaction in sandstones," Geochimica et Cosmochimica Acta, vol. 207, pp. 232-255, 2017.

[34] S. Feng, S. Li, and Y. Lu, "Sequence stratigraphy and architectural variability in Late Eocene lacustrine strata of the Dongying Depression, Bohai Bay Basin, Eastern China," Sedimentary Geology, vol. 295, pp. 1-26, 2013.

[35] R. L. Folk, P. B. Andrews, and D. W. Lewis, "Detrital sedimentary rock classification and nomenclature for use in New Zealand," New Zealand Journal of Geology and Geophysics, vol. 13, no. 4, pp. 937-968, 1970.

[36] L. Zeng and X.-Y. Li, "Fractures in sandstone reservoirs with ultra-low permeability: a case study of the Upper Triassic Yanchang Formation in the Ordos Basin, China," AAPG Bulletin, vol. 93, no. 4, pp. 461-477, 2009.

[37] W. V. Boynton, "Geochemistry of the rare earth elements: meteorite studies," in Rare Earth Element Geochemistry, P. Henderson, Ed., pp. 63-114, Elsevier, 1984.

[38] J. R. Boles and S. G. Franks, "Clay diagenesis in Wilcox sandstones of Southwest Texas: implications of smectite diagenesis on sandstone cementation," Journal of Sedimentary Research, vol. Vol. 49, pp. 55-70, 1979.

[39] B. Thyberg, J. Jahren, T. Winje, K. Bjørlykke, J. I. Faleide, and Ø. Marcussen, "Quartz cementation in Late Cretaceous mudstones, northern North Sea: changes in rock properties due to dissolution of smectite and precipitation of micro-quartz crystals," Marine and Petroleum Geology, vol. 27, no. 8, pp. 1752-1764, 2010.

[40] A. Hyodo, R. Kozdon, A. D. Pollington, and J. W. Valley, "Evolution of quartz cementation and burial history of the Eau Claire Formation based on in situ oxygen isotope analysis of quartz overgrowths," Chemical Geology, vol. 384, pp. 168180, 2014.

[41] C. Peltonen, $\varnothing$. Marcussen, K. Bjørlykke, and J. Jahren, "Clay mineral diagenesis and quartz cementation in mudstones: the effects of smectite to illite reaction on rock properties," Marine and Petroleum Geology, vol. 26, no. 6, pp. 887898, 2009.

[42] O. Walderhaug, "Modeling quartz cementation and porosity in middle Jurassic Brent Group Sandstones of the Kvitebjørn Field, Northern North Sea," AAPG Bulletin, vol. 84, pp. 1325-1339, 2000.

[43] D. Chen, J. Wang, H. Qing, D. Yan, and R. Li, "Hydrothermal venting activities in the Early Cambrian, South China: petrological, geochronological and stable isotopic constraints," Chemical Geology, vol. 258, no. 3-4, pp. 168-181, 2009.

[44] Z. Lei, S. E. Dashtgard, J. Wang et al., "Origin of chert in Lower Silurian Longmaxi Formation: Implications for tectonic evolution of Yangtze Block, South China," Palaeogeography, Palaeoclimatology, Palaeoecology, vol. 529, pp. 53-66, 2019. 
[45] X. Lai, B. Yu, J. Chen et al., "Thermodynamic conditions of framework grain dissolution of clastic rocks and its application in Kela 2 gas field," Science in China Series D: Earth Sciences, vol. 48, no. 1, pp. 21-31, 2005.

[46] S. Gier, R. H. Worden, W. D. Johns, and H. Kurzweil, "Diagenesis and reservoir quality of Miocene sandstones in the Vienna Basin, Austria," Marine and Petroleum Geology, vol. 25, no. 8, pp. 681-695, 2008.

[47] C. Cai, K. Li, D. Liu et al., "Anaerobic oxidation of methane by Mn oxides in sulfate-poor environments," Geology, vol. 49, no. 7, pp. 761-766, 2021.

[48] C. W. Blount, "Barite solubilities and thermodynamic quantities up to 300 degrees C and 1400 bars," American Mineralogist, vol. 62, pp. 942-957, 1977.

[49] E. M. Griffith and A. Paytan, "Barite in the ocean - occurrence, geochemistry and palaeoceanographic applications," Sedimentology, vol. 59, no. 6, pp. 1817-1835, 2012.

[50] Z. Shen, B. Yu, C. Bai, S. Han, and H. Liu, "Origin of beddingparallel calcite veins from Lacustrine Shale in the Eocene Dongying Depression, Bohai Bay Basin, China," Geofluids, vol. 2020, Article ID 8883297, 23 pages, 2020.

[51] L. Wang, W. Hu, X. Wang, J. Cao, and Q. Chen, "Seawater normalized REE patterns of dolomites in Geshan and Panlongdong sections, China: implications for tracing dolomitization and diagenetic fluids," Marine and Petroleum Geology, vol. 56, pp. 63-73, 2014.

[52] G. E. Webb, L. D. Nothdurft, B. S. Kamber, J. T. Kloprogge, and J. X. Zhao, "Rare earth element geochemistry of scleractinian coral skeleton during meteoric diagenesis: a sequence through neomorphism of aragonite to calcite," Sedimentology, vol. 56, no. 5, pp. 1433-1463, 2009.

[53] A. M. Olivarez and R. M. Owen, "REE/Fe variations in hydrothermal sediments: implications for the REE content of seawater," Geochimica et Cosmochimica Acta, vol. 53, no. 3, pp. 757$762,1989$.

[54] C. Cai, K. Li, H. Li, and B. Zhang, "Evidence for cross formational hot brine flow from integrated ${ }^{87} \mathrm{Sr} /{ }^{86} \mathrm{Sr}$, REE and fluid inclusions of the Ordovician veins in Central Tarim, China," Applied Geochemistry, vol. 23, no. 8, pp. 22262235, 2008.

[55] M. Bau and P. Möller, "Rare earth element fractionation in metamorphogenic hydrothermal calcite, magnesite and siderite," Mineralogy and Petrology, vol. 45, no. 3-4, pp. 231-246, 1992.

[56] C. Cai, B. Mei, T. Ma, C. Chen, and C. Liu, "Hydrocarbonwater-rock interactions in the diagenetically altered system near major unconformities in Tarim Basin," Chinese Science Bulletin, vol. 41, pp. 1631-1635, 1996.

[57] Q. Meng, J. Hooker, and J. Cartwright, "Early overpressuring in organic-rich shales during burial: evidence from fibrous calcite veins in the Lower Jurassic Shales-with-Beef Member in the Wessex Basin, UK," Journal of the Geological Society, vol. 174, no. 5, pp. 869-882, 2017.

[58] F. J. Longstaffe, "Oxygen isotope studies of diagenesis in the basal Belly River Sandstone, Pembina I-Pool, Alberta," Journal of Sedimentary Research, vol. 56, pp. 78-88, 1986.

[59] H. Irwin, C. Curtis, and M. Coleman, "Isotopic evidence for source of diagenetic carbonates formed during burial of organic-rich sediments," Nature, vol. 269, no. 5625, pp. 209213, 1977.
[60] J. D. Hudson, "Concretions, isotopes, and the diagenetic history of the Oxford Clay (Jurassic) of central England," Sedimentology, vol. 25, no. 3, pp. 339-370, 1978.

[61] G. A. Wolff, N. Rukin, and J. D. Marshall, "Geochemistry of an early diagenetic concretion from the Birchi Bed," Organic Geochemistry, vol. 19, no. 4-6, pp. 431-444, 1991.

[62] B. B. Bowen, R. I. Ochoa, N. D. Wilkens et al., "Depositional and diagenetic variability within the Cambrian Mount Simon Sandstone: implications for carbon dioxide sequestration," Environmental Geosciences, vol. 18, no. 2, pp. 69-89, 2011.

[63] S. N. Ehrenberg, P. H. Nadeau, and Ø. Steen, "Petroleum reservoir porosity versus depth: influence of geological age," AAPG Bulletin, vol. 93, no. 10, pp. 1281-1296, 2009.

[64] Y. Wang, X. Hao, and Y. Hu, "Orderly distribution and differential enrichment of hydrocarbon in oil-rich sags: a case study of Dongying Sag, Jiyang Depression, Bohai Bay Basin, East China," Petroleum Exploration and Development, vol. 45, pp. 785-794, 2018.

[65] P. D. Lundegard, "Sandstone porosity loss - a "Big picture" view of the importance of compaction," Journal of Sedimentary Research, vol. 62, no. 2, pp. 250-260, 1992. 